This PDF is a selection from a published volume from the National Bureau of Economic Research

Volume Title: Growth and Productivity in East Asia, NBER-East Asia Seminar on Economics, Volume 13

Volume Author/Editor: Takatoshi Ito and Andrew K. Rose, editors

Volume Publisher: University of Chicago Press

Volume ISBN: 0-226-38680-5

Volume URL: http://www.nber.org/books/ito_04-2

Conference Date: June 20-22, 2002

Publication Date: June 2004

Title: Institutions, Volatility, and Crises

Author: Daron Acemoglu, Simon Johnson, James Robinson

URL: http://www.nber.org/chapters/c10745 


\title{
Institutions, Volatility, and Crises
}

\author{
Daron Acemoglu, Simon Johnson, and James Robinson
}

\subsection{Introduction}

There is a growing consensus among economists that differences in institutions, in particular the enforcement of property rights, rule of law, and constraints placed on politicians and elites, have a first-order effect on long-run economic development (see, among others, North and Thomas 1973; Jones 1981; North 1981; Olson 1982). Recent empirical findings support this notion. There is a strong correlation between institutions and economic and financial development (e.g., Knack and Keefer 1995; Mauro 1995; La Porta et al. 1998; and Hall and Jones 1999), especially when we look at the historically determined differences in institutions (e.g., Acemoglu, Johnson, and Robinson 2001, 2002).

In this paper and a companion paper, Acemoglu et al. (2003), we argue that institutions also have a first-order effect on short- and medium-run economic instability. We document that societies that have weak institutions for historical reasons have suffered substantially more output volatil-

Daron Acemoglu is professor of economics at the Massachusetts Institute of Technology (MIT) and a research associate of the National Bureau of Economic Research. Simon Johnson is the Ronald A. Kurtz Associate Professor at the Sloan School of Management, Massachusetts Institute of Technology, and a faculty research fellow of the National Bureau of Economic Research. James Robinson is professor of political science and economics at the University of California-Berkeley.

For helpful comments, we thank our discussants, Steve Dowrick and Dipinder Randhawa, and the editors, Takatoshi Ito and Andrew Rose. For comments on related work we thank Stijn Claessens, Alessandra Fogli, Tatiana Nenova, Sebastián Mazzuca, Ragnar Torvik, seminar participants at New York University and MIT, and attendees at the Asian Institute for Corporate Governance's Second Asian Corporate Governance Conference, the CarnegieRochester Public Policy 2002 conference, and the World Bank Financial Globalization conference for their suggestions. 
ity and experienced more severe output, exchange rate, banking, and political crises over the past thirty years. The link we document between the historically determined component of institutions and economic instability calls for a quite different view of medium-run macroeconomic volatility, and for more work to understand the relationship between institutions and volatility. This paper is therefore meant more as a progress report to encourage others to investigate these issues.

To isolate the historically determined (and plausibly exogenous) component of differences in institutions, we build on Acemoglu, Johnson, and Robinson $(2001,2002)$. These papers focus on countries that were colonized by European powers. This is an attractive sample for understanding the role of institutions in economic development because the intervention of Europeans, setting up very different institutions in various parts of the globe, is the closest we have to a natural social experiment in the creation of institutions. ${ }^{1}$

In Acemoglu, Johnson, and Robinson (2001) we documented that different colonization strategies and different institutions set up by Europeans had radically different implications for economic development. Places prospered when Europeans set up institutions that protected private property rights, enforced the rule of law, and placed tight constraints on politicians and powerful elites. In contrast, areas where Europeans established new extractive institutions, or took over existing ones, stagnated or grew only slowly. We demonstrated the effect of historical institutions on economic development by exploiting variation in the feasibility of large-scale settlements by Europeans. Where the disease environment was favorable for Europeans to settle, Europeans settled in large numbers and developed institutions very similar to, or even substantially better than, institutions in Europe. These settler colonies, such as the United States, Canada, Australia, or New Zealand, have grown steadily over the past 200 years, especially taking advantage of the opportunity to industrialize. In many other colonies - for example, in sub-Saharan Africa, South Asia, and Central America-Europeans faced high or very high mortality rates, and settlement was not feasible. In these areas, the colonizers were much more likely to develop extractive institutions, used mostly to exploit the native population for the benefit of a few rich Europeans, and these institutions have often proved incompatible with sustained rapid growth.

Based on this argument, we used the mortality rates faced by European settlers as an instrument for institutional development and current institutions. Figure 3.1 shows the reduced-form relationship between income per capita (our measure of long-term development) today and mortality rates

1. There may also be differences in the institutional development of colonized and noncolonized countries (e.g., Japan and Thailand), but this is harder to analyze and not part of this paper. 


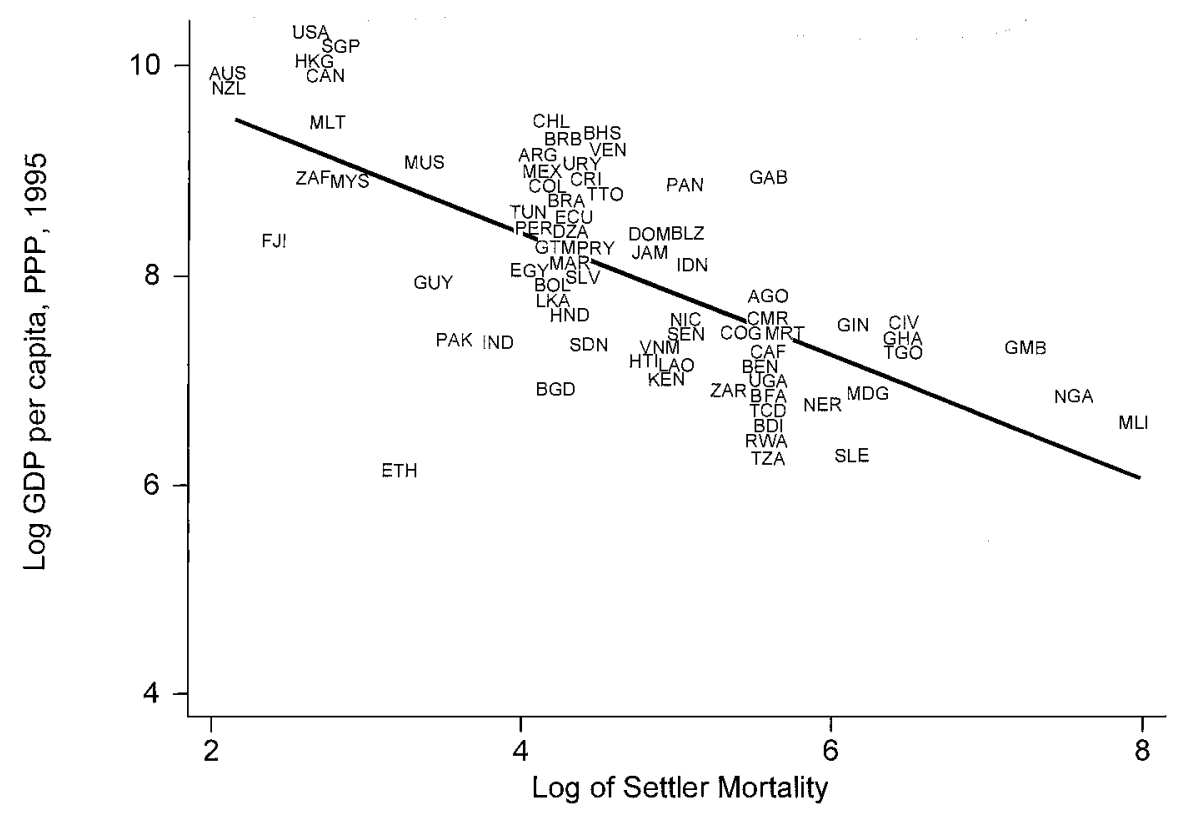

Fig. 3.1 Settler mortality and income today

faced by settlers (log of the mortality rates per annum per 1,000 settlers, where each person who dies is replaced) more than 150 years ago. There is a strong and robust relationship. Places where Europeans faced much higher mortality rates are significantly poorer today. In Acemoglu, Johnson, and Robinson (2001) we documented that the relationship between income per capita today and settler mortality in the past most likely works through institutional development, does not reflect the effect of diseases on the local population, and is not caused by other omitted characteristics that are correlated with the mortality rates faced by settlers.

The current paper highlights a surprisingly strong relationship between these mortality rates and various measures of instability and crises during the past thirty to forty years. As in Acemoglu, Johnson, and Robinson (2001), our interpretation is that this relationship reflects the effect of historically determined institutions (more specifically, institutions shaped by differential European colonization strategies and settlement patterns) on instability. In other words, not only did societies that inherited extractive institutions from their colonial past fail to take advantage of development opportunities over the long run, but their recent medium-run experience has been characterized by frequent crises and substantial instability.

Figures 3.2, 3.3, and 3.4 show the relationship between our (log) settler mortality measure and various measures of volatility since 1970. Figure 3.2 shows the relationship between the standard deviation of gross domestic 


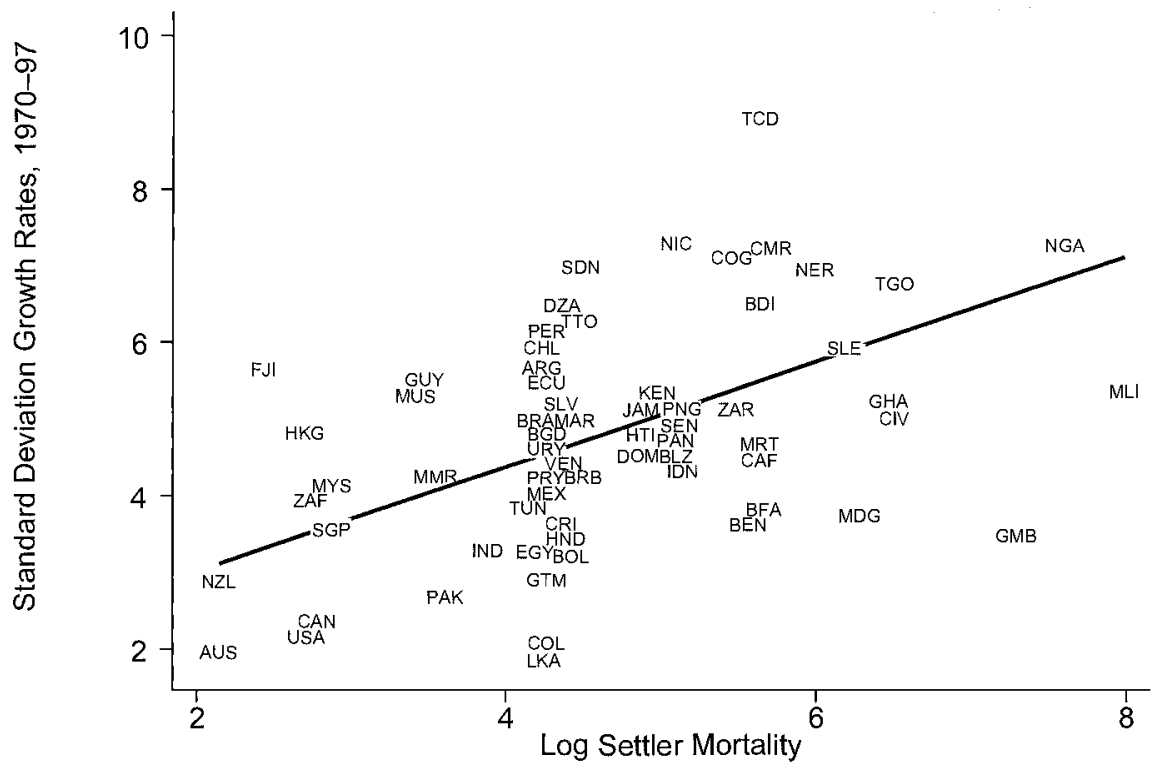

Fig. 3.2 Volatility of output against log settler mortality

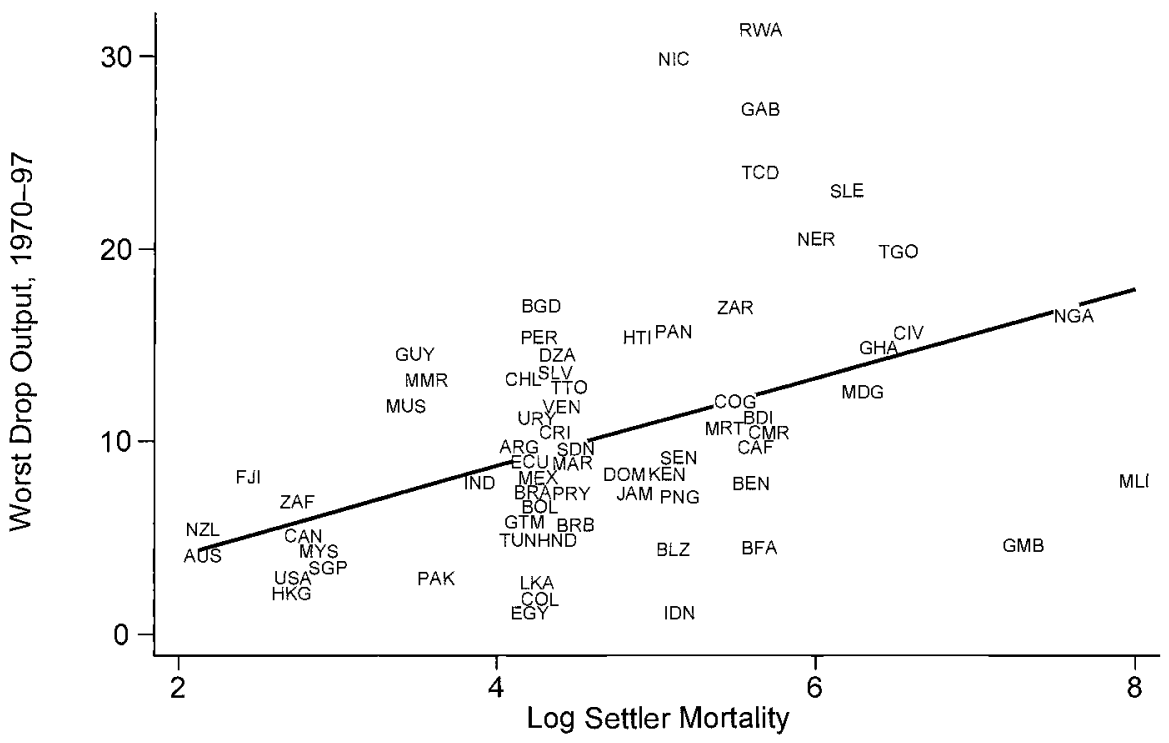

Fig. 3.3 Worst output drop against log settler mortality 


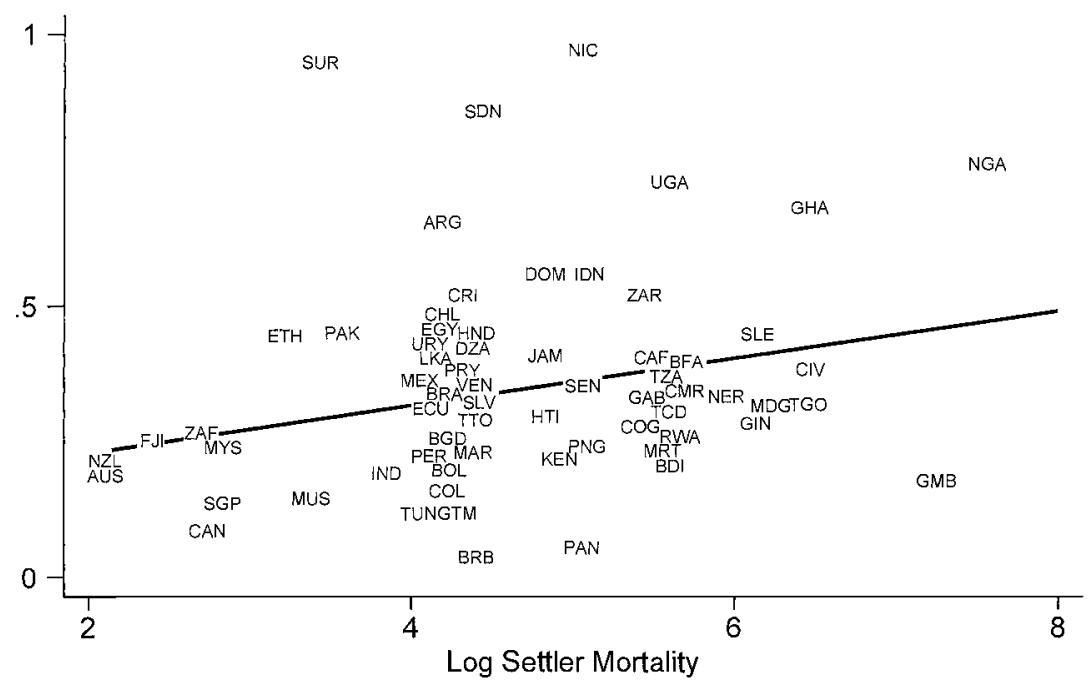

Fig. 3.4 Largest real exchange rate depreciation against log settler mortality

product (GDP) growth between 1970 and 1997 and settler mortality. ${ }^{2}$ Figure 3.3 depicts the relationship between the largest output drop during the same period (as a measure of severity of crises) and settler mortality. Figure 3.4 presents the largest real exchange rate depreciation against settler mortality as a way of showing the relationship between balance-ofpayment crises and our measure of historical institutions. These figures document that there is a strong relationship between this historical variable and the propensity of these societies to experience output volatility, severe output collapses, and balance-of-payment crises. We will show later that there is also a strong robust positive relationship between log settler mortality and the incidence of banking and political crises. ${ }^{3}$

Our argument is that these reduced-form relationships reflect the effect of institutions on economic instability. Societies with weak institutions not

2. We drop two outliers, Gabon and Rwanda, from this figure to make the pattern clearer. This does not change the relationship, and these countries are included in the regression analysis that follows.

3. The reduced-form coefficients on log settler mortality in the regressions corresponding to figures $3.1,3.2$, and 3.3 are 0.66 (standard error $0.18, R^{2} 0.19,67$ observations) using output volatility, 2.3 (standard error $0.6, R^{2} 0.19,68$ observations) using worst output drop, and 0.038 (standard error $0.021, R^{2} 0.05,66$ observations) using largest real exchange rate depreciation. In addition, we report results for banking crises and political crises. The regression of a dummy for a systemic banking crisis on log settler mortality gives a coefficient of 0.15 and the standard error is 0.062 , with 37 observations and an $R^{2}$ of 0.15 . The regression of a dummy for political crisis on log settler mortality gives a coefficient 0.15 , and the standard error is 0.039 , with 80 observations and an $R^{2}$ of 0.17 . 
only fail to take advantage of economic opportunities but also experience significant political struggles and associated economic instability. In the rest of the paper, we build the case that the relationship between settler mortality and instability indeed reflects the causal effect of institutions on economic and political instability. We also show that this relationship is robust to the inclusion of various controls for other potential determinants of instability. The same relationship also holds if we restrict the sample to just countries above median world income or to just former British colonies.

Our results suggest that there is a first-order effect of institutions on economic and political instability. In short, institutional weaknesses not only cause slow growth over long periods of time (e.g., 50-100 years) but are also associated with higher volatility and instability over 20 - to 40 -year periods. Although there are natural and intuitive reasons to expect such a relationship between institutions and instability, the precise mechanisms are not clear. A great deal more research is needed on the theoretical and empirical relationship between institutional weaknesses and instability.

In a related work, Acemoglu et al. (2003) show that the results reported here for output volatility and worst drop in output are robust to including a wide range of alternative measures of institutions and macroeconomic variables. They also present evidence that institutions determine macroeconomic policies such as government consumption and the extent of real exchange rate overvaluation, and that these distortionary macroeconomic policies have little effect on volatility once the direct effect of underlying institutions is taken into account.

The rest of the paper is organized as follows. The next section motivates the use of settler mortality as an instrument for the historically determined component of institutions. It also describes the settler mortality variable and shows the relationship between settler mortality and current institutions. Section 3.3 documents the relationship between various measures of instability and the historically determined component of institutions. It also documents that these relationships are robust to the inclusion of the obvious control variables. Section 3.4 concludes.

\subsection{Historical Determinants of Institutions in Former European Colonies}

\subsubsection{Settler Mortality as an Instrumental Variable}

The set of former European colonies provides an attractive sample for isolating the historically determined component of institutions, since the institutions in almost all former colonies have been heavily influenced by their colonial experience (see La Porta et al., 1998, and Acemoglu, Johnson, and Robinson, 2001, for more detailed discussions). Specifically, many important dimensions of institutions in former colonies were shaped by the strategy of colonization.

In Acemoglu, Johnson, and Robinson (2001, 2002), we contrasted insti- 
tutions of private property, which place effective constraints on elites and rulers and do protect the property rights of a broad segment of society, and extractive institutions, which fail to impose constraints on elites and politicians and do not provide secure property rights for the majority of the population. We argued that institutions of private property were more likely to arise when Europeans settled in large numbers and set up institutions protecting economic and political rights for themselves. The "neo-Europes"the United States, Canada, Australia, and New Zealand - are perhaps the best examples of European settlement associated with the development of good institutions. In contrast, extractive institutions emerged when Europeans pursued a strategy of extracting various types of resources from the colonies without settling and without developing participatory institutions. Note that we are not arguing that institutions are immutable and unchanging over time. Rather our historical analysis suggests that institutions persist: that is, although institutions do change over time, the initial colonial form of these institutions continues to have some effect for at least several hundred years.

This reasoning suggests that in places where the disease environment was not favorable to European health and settlement Europeans could not settle, and the cards were stacked against the development of institutions of private property. Based on this reasoning, we use measures of mortality rates experienced by early actual and potential European settlers in the colonies as an instrument for historical and current institutions in these countries. Schematically, the reasoning underlying this instrumentation strategy is

(potential) $\rightarrow$ settlements $\rightarrow \underset{\text { institutions }}{\text { early }} \rightarrow \underset{\text { institutions }}{\text { current }} \rightarrow \begin{aligned} & \text { current } \\ & \text { performance } \\ & \text { mortality }\end{aligned}$

Based on this reasoning, we use data on the mortality rates of soldiers, bishops, and sailors stationed in the colonies between the seventeenth and nineteenth centuries (Curtin 1989, 1998; Gutierrez 1986). These give a good indication of the mortality rates faced by settlers. Europeans were well informed about these mortality rates at the time, even though they did not know how to control the diseases that caused these high mortality rates, especially yellow fever and malaria (see Acemoglu, Johnson, and Robinson, 2001, for more detail). ${ }^{4}$

An important issue is of course the validity of the exclusion restriction presumed by this instrumentation strategy - that is, whether the mortality rates faced by the settlers between the seventeenth and nineteenth centuries could actually have an effect on current outcomes through another channel. Our instrument would not be valid, for example, if there were a

4. The differences in mortality rates were large (see appendix table A2 in Acemoglu, Johnson, and Robinson 2001). For a settlement size maintained through replacement of 1,000 Europeans before 1850, the annual mortality rates ranged from 8.55 in New Zealand (lower than in Europe at that time) to 49 in India, 130 in Jamaica, and around 500 in West Africa. 
strong correlation between European mortality rates over 150 years ago and the health of the current population or climate, and if current health and climate affects current economic outcomes. However, the majority of European deaths in the colonies were caused by malaria and yellow fever. Although these diseases were fatal to Europeans, who had no immunity, they had much less effect on indigenous adults, who had developed various types of immunities. These diseases are therefore unlikely to be the reason why many countries in Africa and Asia are poor today.

This notion is supported by the mortality rates of local people in highsettler mortality areas, which were comparable to the mortality rates of British troops serving in Britain or in healthier colonies. Moreover, yellow fever is essentially eradicated today, so this component of the mortality rates faced by Europeans more than 150 years ago should not have a direct effect on income or other outcomes today. To substantiate the validity of our instrumentation approach, in Acemoglu, Johnson, and Robinson (2001) we showed that the results are robust to controlling for climate, humidity, other geographic variables, and current health conditions, and that we obtain very similar results by exploiting only differences in European mortality due to yellow fever. On the basis of these findings, we take mortality rates of European settlers between the seventeenth and nineteenth centuries as an instrument for current institutions in the former colonies.

\subsubsection{Measuring Contemporary Institutions}

What are the institutions that matter? In our empirical analysis here, we use an institutional variable for which we have data for a broad cross section of countries at the beginning of the sample: constraints placed on the executive, as measured in the Polity IV data set based on the work of Robert Gurr. For every independent country, the Polity IV data set reports a qualitative score, between 1 and 7 , measuring the extent of constitutional limits on the exercise of arbitrary power by the executive. This "constraint on the executive" variable is conceptually attractive because it measures institutional and other constraints that are placed on presidents and dictators (or monarchies).

Theoretically, we expect a society where elites and politicians are effectively constrained to experience less infighting between various groups to take control of the state, and to pursue more sustainable policies (see Acemoglu et al. 2003). Nevertheless, constraint on the executive is only one measure of institutions, and it is quite possible that a country might have adequate constraints on the executive, but suffer from corruption or weak property rights for other reasons. More generally, the relevant institutions are a cluster of social arrangements that include constitutional and social limits on politicians' and elites' power, the rule of law, provisions for mediating social cleavages, strong property rights enforcement, a minimum amount of equal opportunity, and the like. This cluster determines whether agents with investment opportunities will undertake these investments, 


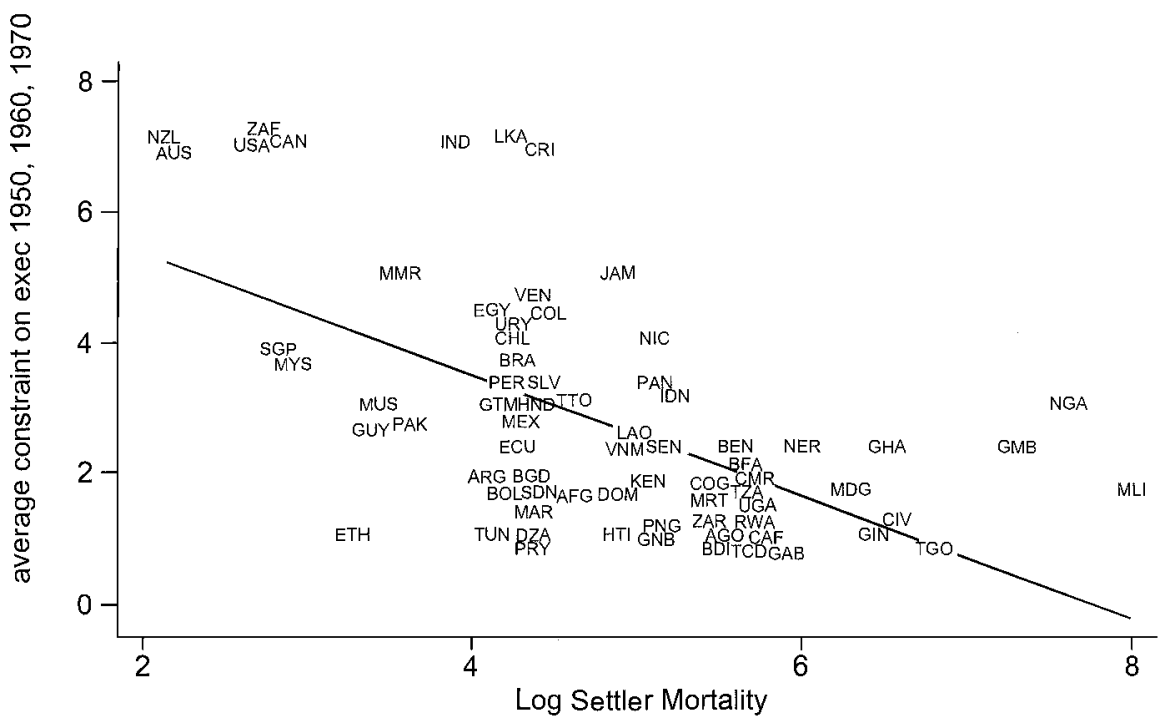

Fig. 3.5 Average constraint on executive $(1950,1960,1970)$ versus log settler mortality

whether there will be significant swings in the political and social environment leading to crises, and whether politicians will be induced to pursue unsustainable policies in order to remain in power in the face of deep social cleavages. Therefore, we prefer to be relatively loose on what the fundamental institutional problems are, and instead we try to isolate the historically determined component of these institutional differences.

Figure 3.5 shows the first-stage relationship between our constraint on the executive variable (average value for 1950,1960, and 1970) and the log of European settler mortality in annualized deaths per thousand mean strength. This measure reports the death rate among 1,000 soldiers per year where each death is replaced with a new soldier and was the standard measure in the army records from which much of our information comes. We use logs rather than levels, because otherwise some of the African observations are extreme outliers. The figure shows a strong relationship between the measure of institutions used in this paper and settler mortality more than 150 years ago. Our interpretation is that this reflects the causal effect of colonial policies on current institutions, and hence it can serve as a useful source of variation for identifying the effect of institutions on macroeconomic outcomes.

\subsubsection{Institutions and Economic Outcomes}

We now briefly examine the relationship between the historically determined component of institutions and current per capita income and recent growth rates. The first column in panel A of table 3.1 replicates our main 


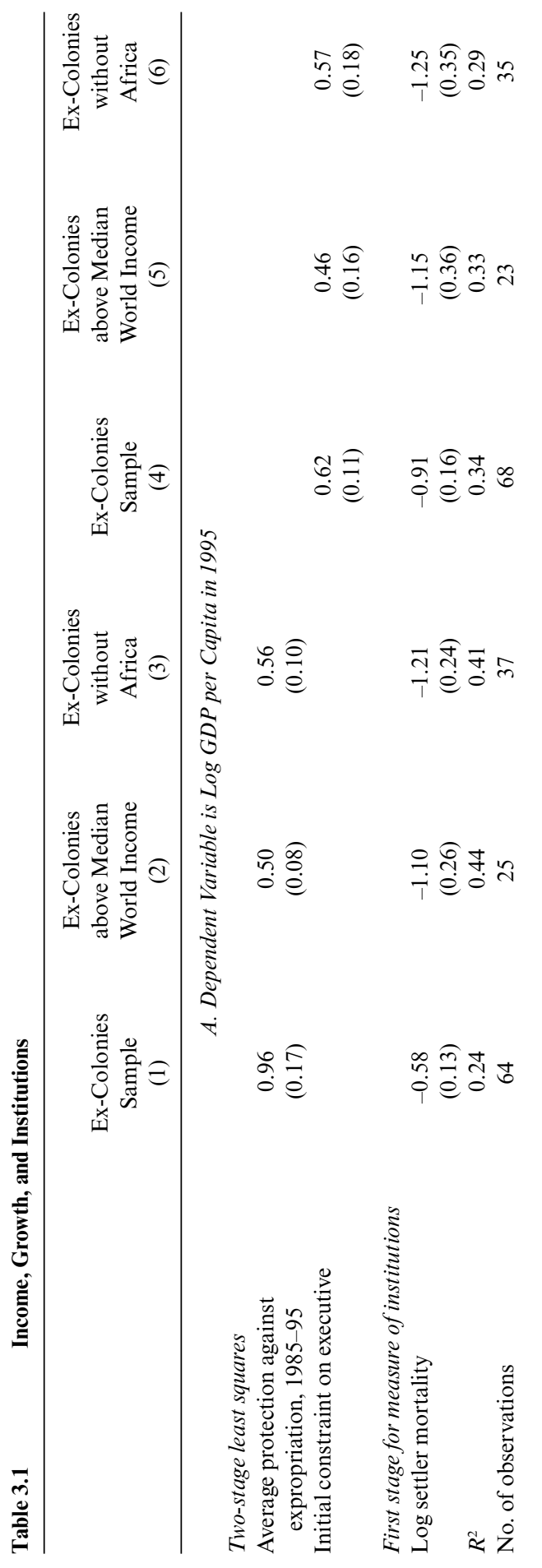




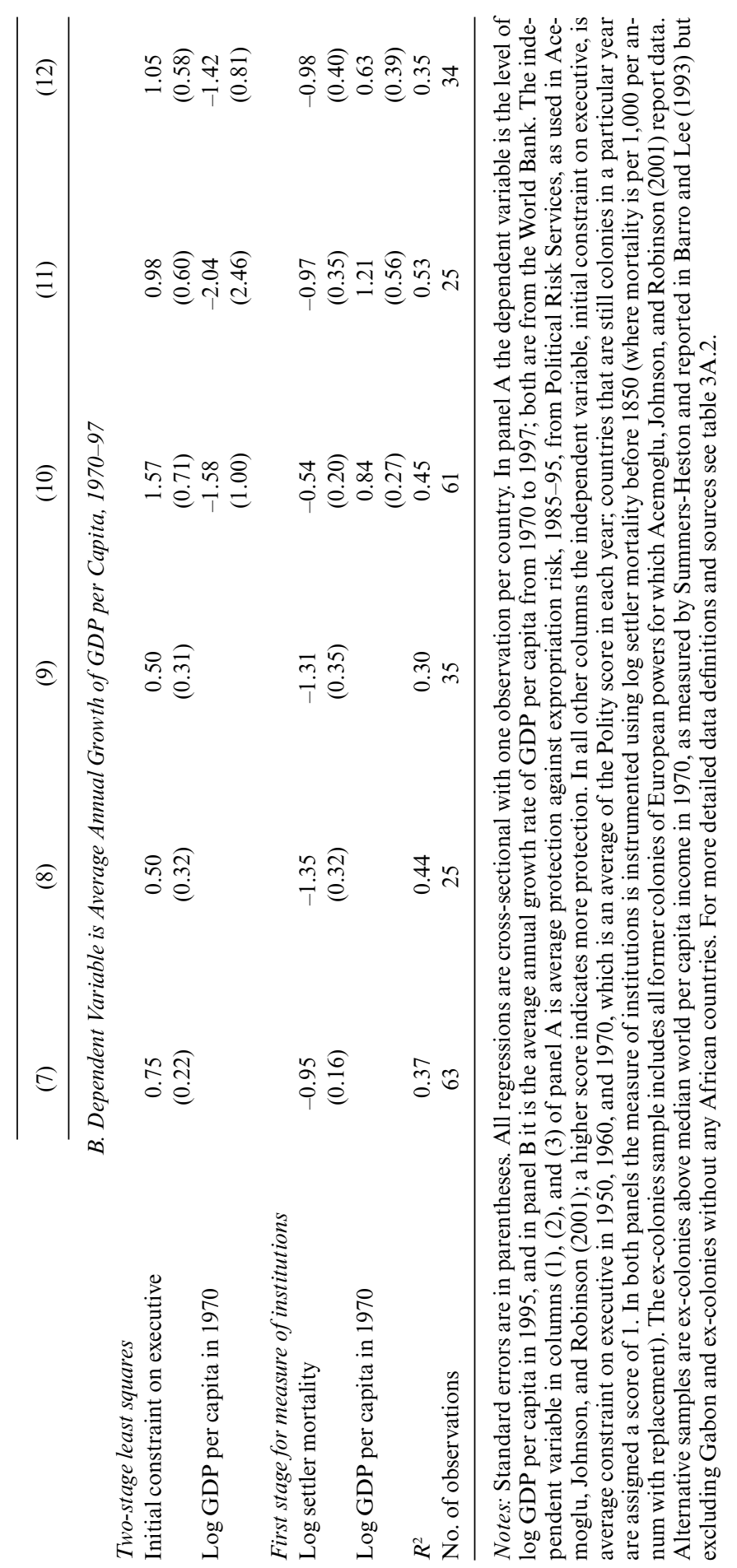


regression from Acemoglu, Johnson, and Robinson (2001), which looks at the effect of institutional differences on ( $\log$ ) income per capita today. Our two-stage least squares (2SLS) estimate of the effect of institutions on income per capita is relatively precisely estimated and large. For example, it implies that improving Nigeria's institutions to the level of Chile could lead to a sevenfold increase in Nigeria's income (Chile currently has per capita income more than eleven times that of Nigeria). ${ }^{5}$

The lower part of panel A shows the first-stage relationship between institutions and log of potential European settler mortality. In Acemoglu, Johnson, and Robinson (2001), we used average protection against expropriation risk between 1985 and 1995 as our measure of institutions. We do not focus on this measure in the current paper, since we prefer a measure that refers to the beginning of our sample period (i.e., 1970), and the protection against expropriation variable is not available for the 1960s and 1970s. Column (4) replicates the same regression as column (1) with the "constraint on the executive" variable that we use throughout this paper. The first-stage relationship for this regression is shown in figure 3.5. Mortality rates faced by early European settlers explain over 25 percent of the variation in this measure of current institutions.

Columns (7) and (10) turn to a regression of the average growth rate between 1970 and 1997 on constraint on the executive before 1970, again instrumented by log settler mortality (with or without controlling for initial income). We express growth rates in percentage points (e.g., 2 percent rather than 0.02) to save on decimal points; see table $3 \mathrm{~A} .3$ for summary statistics. Column (7) shows a statistically significant relationship, indicating faster growth since 1970 among countries with better historically determined institutions. For example, the coefficient of 0.75 implies that a country like the United States, with a value of constraint on the executive of 7, is predicted to grow about 3 percent a year faster than a country like Nigeria, with a score of 3 . The estimate of the effect of initial "constraint on the executive" on growth becomes larger when we control for initial income in column (10), but also the standard error more than triples (the coefficient is still statistically significant at the 5 percent level). ${ }^{6}$

It is useful to know whether the relationship between the historically determined component of institutions and economic outcomes is driven

5. Note that the comparisons of countries here and later in the text are only intended to be illustrative. They do not imply anything about the "fit" of the regression.

6. That the effect of historically determined institutions on post-1970 growth becomes weaker when we control for initial income is not surprising. Initial income (i.e., income per capita 1970) is determined largely by historical institutions, so our measure of institutions and initial income are highly correlated. In fact, much of the divergence among the former colonies took place between 1750 and 1950, when countries with good institutions took advantage of industrialization opportunities and those with extractive institutions failed to do so (see Acemoglu, Johnson, and Robinson, 2002). So our measure of institutions is as good a determinant of income level in 1970 as subsequent growth. 
mainly by the contrast between rich and poor nations. Columns (2), (5), (8), and (11) report regressions for countries above the median world per capita income in 1970 (using the Summers-Heston income per capita data for that year, from Heston, Summers, and Aten 2002). In these regressions, and all those in subsequent tables that use this subsample, we drop Gabon, which is an outlier with high volatility (including Gabon in this sample does not change the results). In table 3.1, the estimates for this subsample are similar to, but lower than, those for the sample of all ex-colonies. They continue to be highly significant in income level regressions (columns [2] and [5]) but are only significant at the 10 percent level in the growth regressions (columns [8] and [11]).

Finally, columns (3), (6), (9), and (12) report regressions for ex-colonies without Africa, to show that the effect of the historically determined component of institutions on income level and growth is not driven by a contrast between African and non-African nations. In this smaller sample, the 2SLS estimate of the effect of institutions on economics outcome is again lower than that for all ex-colonies. Nevertheless, this estimate is still significant at the 5 percent level in the income level regressions and significant at the 10 percent in the growth regressions. In the subsequent analysis, we find that the results without Africa are similar to those that use former colonies above median world per capita income, so we just report the latter. $^{7}$

\subsection{Institutions and Measures of Crises}

\subsubsection{Identification Strategy}

The economic relationship we are interested in identifying is

$$
X_{c, t-1, t}=\alpha+\beta \cdot I_{c, t-1}+Z_{c, t-1, t}^{\prime} \cdot \gamma+\varepsilon_{c, t-1, t},
$$

where $X_{c, t-1, t}$ is the outcome of interest for country $c$ between times $t$ and $t-1$. The five outcomes that we will look at are overall volatility (standard deviation of growth), severity of crises (worst output drop), largest real exchange rate depreciation, a dummy for banking crises, and a measure of political crises. In our baseline regressions, the time period will be from 1970 to 1997 (this choice is dictated by data availability and our desire to start the analysis at a point in time where all countries in our sample are independent nation states). We examined alternative time periods, for example starting in 1960 or 1980, and did not find any important difference in results.

7. Omitting Africa is also informative on the question of whether the length of colonial control was important. Much of Africa was under formal colonial rule only briefly. Nevertheless, it was under European influence since at least 1600 through slave trading and other interactions. 
$I_{c, t-1}$ is our measure of institutions at the beginning of the sample, constructed as the average value for the constraint on the executive measure from the Polity IV data set for 1950, 1960, and 1970. In taking this average, we assign the lowest score to countries that are not yet independent (and that are therefore not in the Polity IV data set). ${ }^{8}$ This is reasonable because in a country still under colonial control there are typically few real constraints on the power of the rulers. In addition, $Z_{c, t-1, t}$ is a set of other controls, ranging from macro variables, to financial development variables, to other determinants of economic instability, such as terms of trade shocks etc. ${ }^{9}$

The parameter that we are interested in identifying is $\beta$, the effect of institutions. The simplest strategy is to estimate the model in equation (1) using ordinary least squares (OLS) regression. There are two problems with this strategy: (1) Institutions are endogenous, so we may be capturing reverse causality, or the effect of some omitted characteristics (geography, culture, or other variables) on both institutions and economic outcomes; and (2) institutions are measured with error, and the variable we have does not correspond to the desired concept. In particular, although the institutions we have in mind are multidimensional, constraint on the executive only measures one of these dimensions, and that quite imperfectly.

Both of these concerns imply that OLS regressions will give results that are difficult to interpret and that do not correspond to the causal effect of institutions and policy variables on economic outcomes. Ideally, we would like to estimate equation (1) using 2SLS with a plausible instrument for institutions. This instrument should be correlated with the endogenous regressors and should be orthogonal to any other omitted characteristics and not correlated with the outcomes of interest through any channel other than their effect via the endogenous regressors (i.e., institutions).

In this paper, we pursue the strategy of instrumenting for institutions using the historically determined component of institutions, specifically from the colonial experience of former colonies, as discussed in the previous section. To the extent that the instrument is valid, it will solve the endogeneity, the omitted variables bias, and the measurement error prob-

8. We take these averages rather than simply using the 1970 value of the index, since we are interested in the long-run component of these constraints (not in the year-to-year fluctuations) and also because the Polity data set gives very high scores to a number of former colonies in 1970 that subsequently drop by a large amount. This reflects the fact that many of these countries adopted the constitution of their former colonial powers but did not really implement the constitution or introduce effective checks. Using simply the 1970 value of the constraints on the executive gives very similar results.

9. In Acemoglu et al. (2003) we report regression results with and without the log of initial income per capita. Following Barro (1991) this variable is included in most growth regressions to control for convergence effects. It is also useful to include it in regressions of volatility or crises because, as shown in Acemoglu and Zilibotti (1997), poorer countries suffer substantially more volatility. However, we find that including initial income per capita does not change our basic results, so it is omitted here. This suggests that institutions affect volatility through mechanisms other than their effect on income per capita. 
lems. In particular, if the instrument is valid, we can estimate the effect of institutions on economic outcomes, the $\beta$ parameters, consistently in models that exclude other potentially endogenous controls, such as the macro policy variables. In Acemoglu et al. (2003), we adopt a variety of strategies to deal with the potential endogeneity of macro policy variables. Here we simply treat all controls, including the macro variables, as exogenous. This strategy typically creates an upward bias in the effect of these controls and a potential downward bias in $\beta$, the effect of institutions on instability (see the appendix of Acemoglu, Johnson, and Robinson 2001). We therefore pursue this strategy here since it is conservative, in the sense of stacking the cards against finding a substantial role for institutions.

\subsubsection{Output Volatility}

Table 3.2 shows the relationship between institutions and volatility. Column (1) reports the OLS relationship between the standard deviation of output growth (measured by real GDP per capita) and our measure of institutions. This OLS relationship is shown in figure 3.6. Column (2) shows the estimated 2SLS result when we instrument for institutions using log settler mortality. These results suggest that countries with institutional problems suffer substantially more volatility. For example, the estimate of -0.79 in column (2) implies that a 1 point higher score in the institutional index translates into about a 0.79 decline in the standard deviation of growth. To get an idea of magnitudes, note that on the basis of this estimate, we should expect a country like the United States, which has an institutional score of 7, to have a standard deviation 3.16 lower than a country like Nigeria, which has an institutional score of $3 .^{10}$

Columns (4) through (9) show that the 2SLS relationship between output volatility and institutions is robust when we include the obvious control variables. Column (4) controls for three important macroeconomic variables: log average inflation, which is the log of average annual inflation in the Consumer Price Index from 1970 to 1997, from the World Bank; government consumption, which is the average of the ratio of real government "consumption" expenditure to real GDP from 1970 to 1989, from the Barro and Lee (1993) data set; and real exchange rate overvaluation, which is an index of real overvaluation of the official exchange rate during 197098, constructed by Easterly and Levine (2003) using the methodology of Dollar (1992). In this case, the coefficient on institutions falls in absolute value to -0.48 but remains significant. None of the macro variables are significant. ${ }^{11}$

10. This gap is approximately two-thirds of the actual gap in standard deviation between the United States (7.37) and Nigeria (2.16) in the data, which is 5.21. This comparison is for illustrative purposes only and not to show the fit of the regression.

11. Acemoglu et al. (2003) look at alternative macroeconomic variables and present a larger set of specifications. The only macro variable that is typically significant is the extent of real exchange rate overvaluation. 


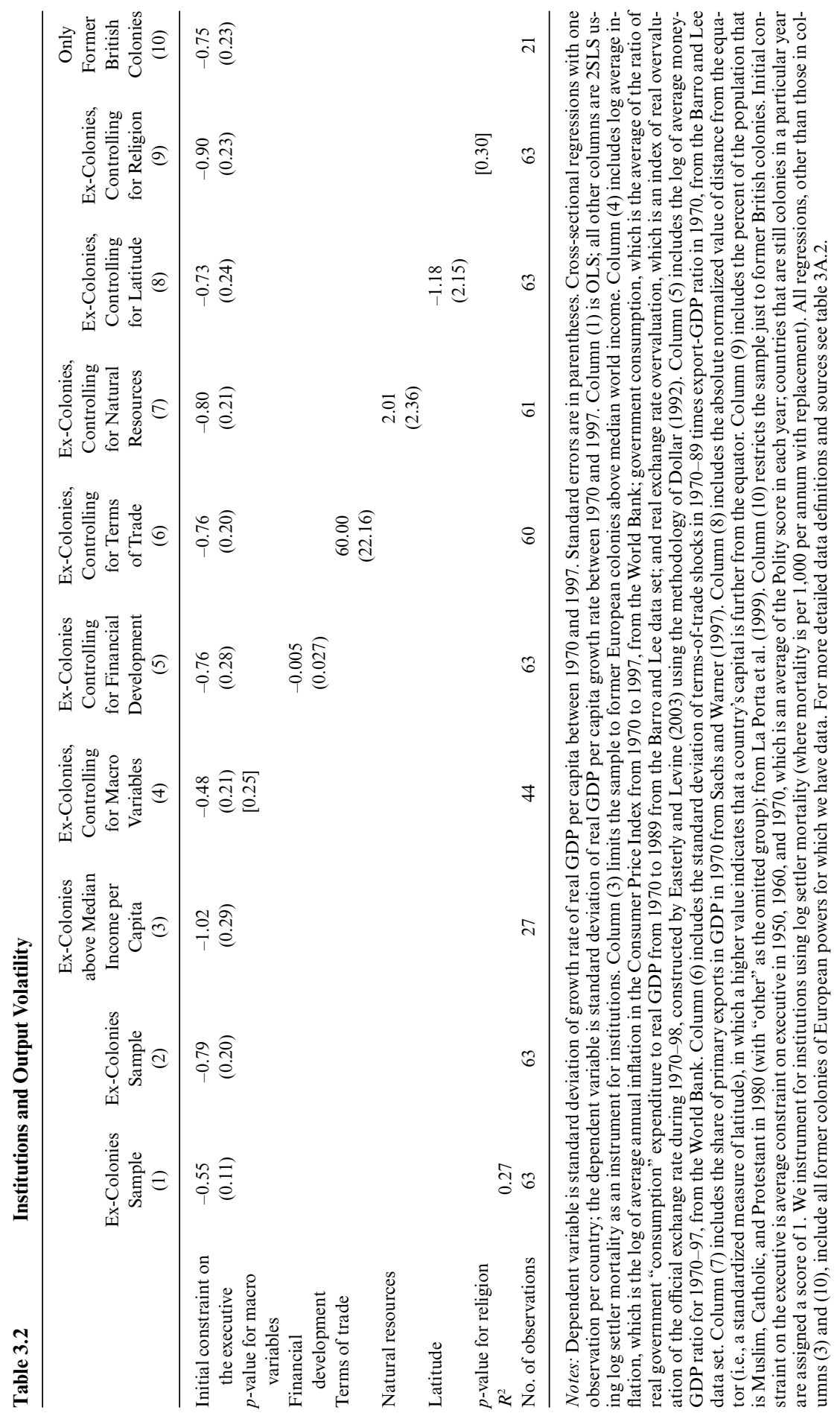




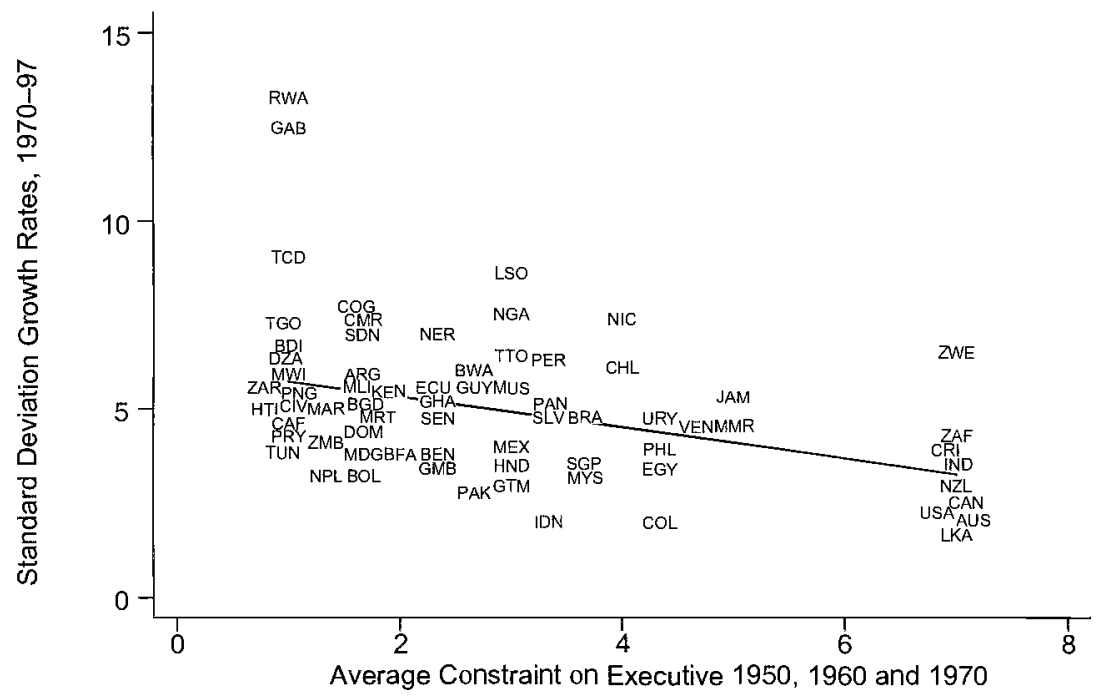

Fig. 3.6 Volatility of output against average constraint on executive

Column (5) includes the log of M2 over GDP, using averages for 197097 (see Easterly, Islam, and Stiglitz, 2000, for the use of this variable in this context). Many macroeconomists emphasize weak financial intermediation as a primary cause of economic volatility. We also find no strong evidence supporting this claim. The financial intermediation variables are not significant, while the institutions variable is still significant, with a coefficient of -0.76 and standard error of 0.28 .

Column (6) includes the standard deviation of terms of trade shocks in 1970-89 times export-GDP ratio in 1970, from the Barro and Lee (1993) data set. This measures the openness to the economy and, in particular, its vulnerability to fluctuations in traded goods prices (e.g., this measure is higher if the country exports more primary commodities). In this column the coefficient on institutions is essentially unchanged compared with our base case: coefficient of -0.76 (standard error of 0.2 ). This measure of the terms of trade is also significant.

Column (7) includes the share of primary exports in GDP in 1970 from Sachs and Warner (1997). This is both a basic measure of openness and exposure to shocks and a way to control for the importance of natural resources in the economy. In this case the coefficient on institutions increases to -0.8 , while the standard error is virtually unchanged at 0.21 .

Column (8) includes the absolute value of latitude (distance of a country's capital from the equator). This is a standard control variable representing the potential effect of geographical factors. Here the coefficient on institutions falls slightly in absolute value to -0.73 , and the standard error 
increases to 0.24 , but institutions are still highly significant. Latitude itself is not significant.

Column (9) includes the fraction of the population that was Muslim, Catholic, and Protestant in 1980 (with "other" as the omitted group; see La Porta et al. 1999). The coefficient on institutions now increases in absolute size to -0.9 , and the standard error is 0.23 . The religion variables are jointly not significant.

Columns (3) and (10) look at subsamples of our ex-colonies sample. Column (3) includes only those former colonies that have above-median world income per capita. In this case, we find a larger coefficient in absolute terms $(-1.02)$ and a somewhat higher standard error (0.29). Column (10) restricts attention to just those countries that were formerly British colonies. In this case the coefficient $(-0.75)$ and standard error $(0.23)$ are almost identical to those reported in column (2).

Overall these results indicate two robust findings. The first is that initial institutions are strongly correlated with subsequent output volatility. The second is that most other potential control variables are not significant determinants of volatility. This is the case even though, to stack the cards against us, we use contemporaneous values of these controls, so any endogeneity (e.g., more volatility leading to less financial development) would tend to bias the coefficients upward. The only significant determinant of volatility in table 3.2, other than institutions, is terms-of-trade shocks.

\subsubsection{Worst Drop in Output}

Table 3.3 presents a number of specifications that look at the impact of institutions on the severity of crises, measured by the largest output drop between 1970 and 1997. In the IV regressions, our measure of institutions - constraint on the executive-is instrumented by European settler mortality. We use the same control variables and alternative samples as in table 3.2.

Worst output drop is defined so that a larger positive number means a bigger fall in GDP per capita. The OLS coefficient on institutions, in column (1), is -1.28 , and the standard error is 0.41 . The OLS relationship is shown in figure 3.7. When we instrument for institutions - for example, in column (2) - the coefficient increases in absolute value to -2.27 , while the standard error rises to 0.7 .

The alternative specifications in table 3.3 show that institutions are robustly significant. Including the macro variables in column (4) reduces the coefficient on institutions slightly, but again the macro variables themselves are not jointly significant. Financial development (column [5]), terms of trade (column [6]), natural resource exports (column [7]), latitude (column [8]), and religion (column [9]) are all insignificant. In almost all cases the coefficient on institutions is above 2 in absolute value; the exceptions are when we control for financial development (column [5]) and when we restrict the 


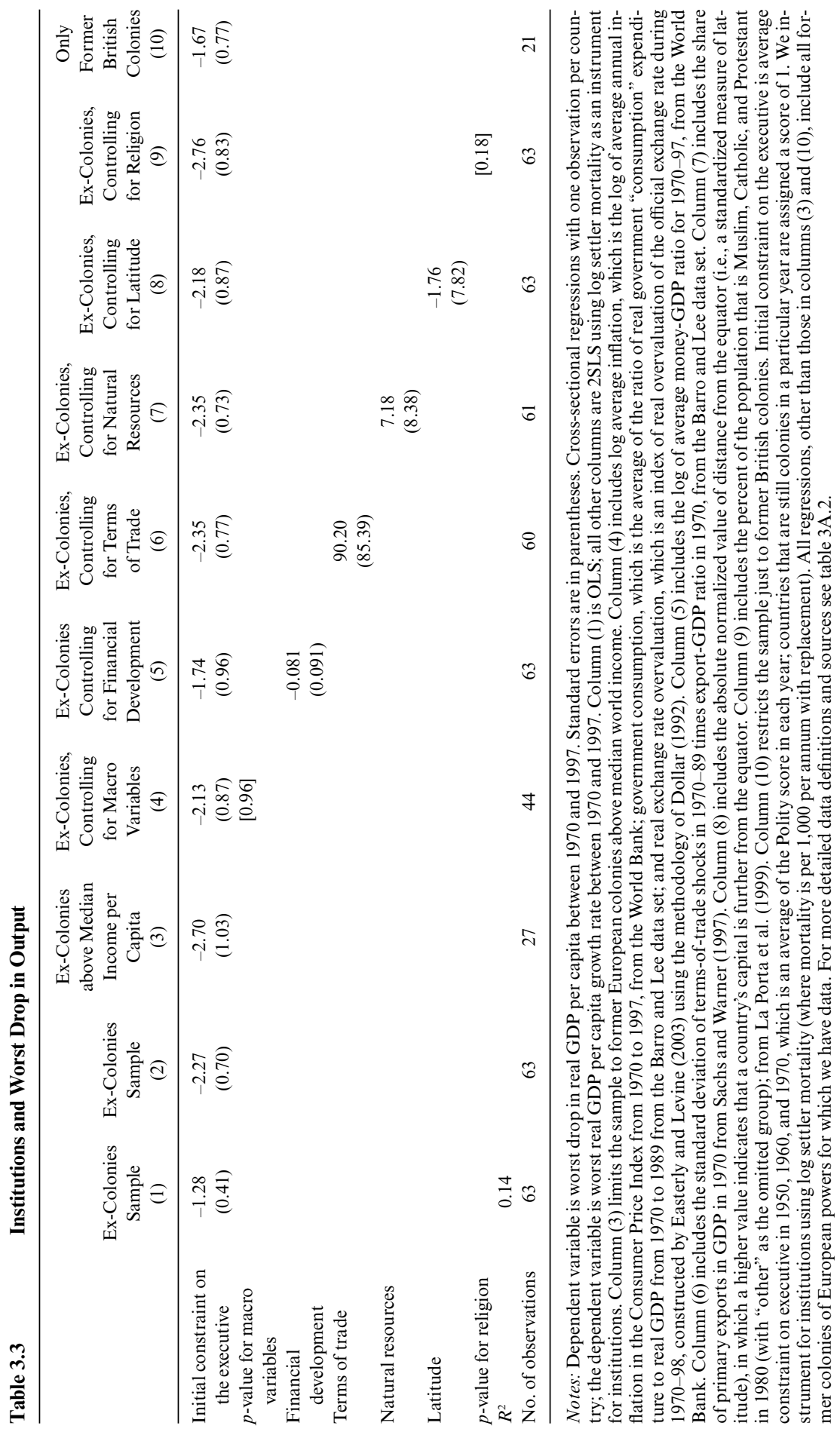




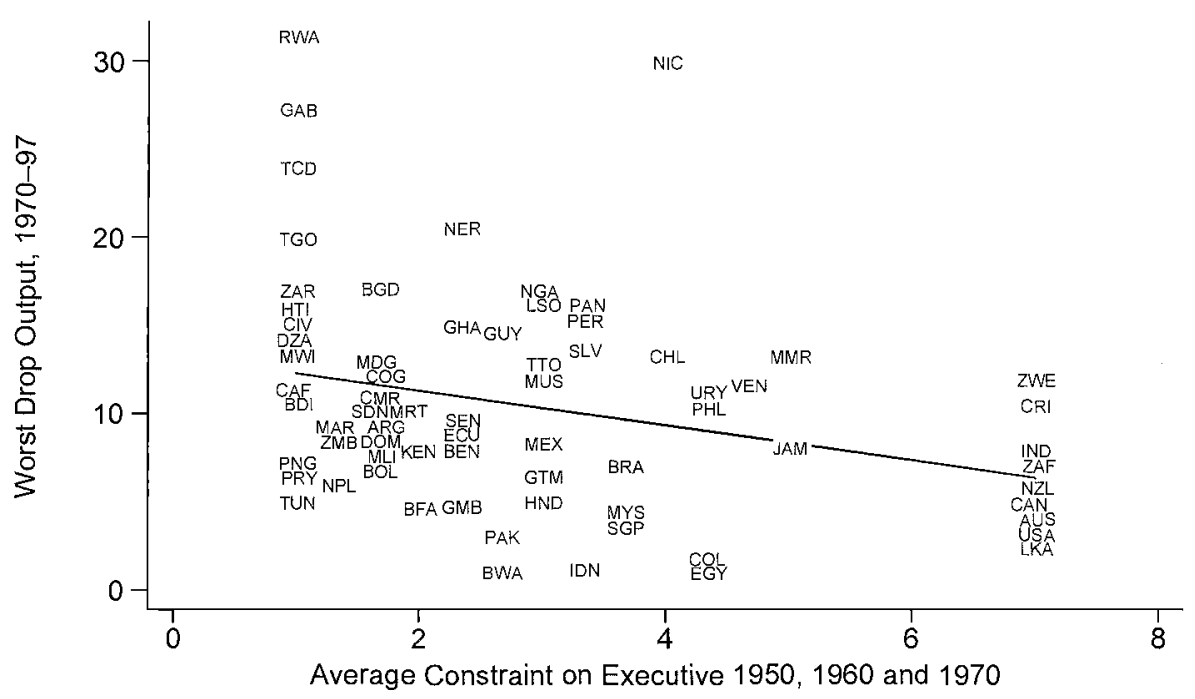

Fig. 3.7 Worst output drop, 1970-97, against average constraint on executive

sample to just former British colonies (column [10]); but even in these cases the institutions coefficient remains significant (although only at the 10 percent level in column [5]). Overall, the results are very similar to our baseline results, showing that the effect of the historically determined component of institutions on output collapses is robust and is not simply driven by some other sources of output crises that are correlated with institutions.

These results confirm the conclusion of the previous section that there appears to be a close link between institutions and economic instability, most likely not mediated primarily through the standard macroeconomic variables or through financial development or through reliance on primary exports. The baseline coefficient estimate is again very large; it suggests that between 1970 and 1999 Nigeria is likely to have experienced a worst output drop around 10 percentage points worse than that of the United States (the actual difference in worst output drop is 13 percentage points).

\subsubsection{Exchange Rate Crises}

Are institutions also related to exchange rate and balance-of-payments crises? To answer this question, we use change in the real exchange rate as a rough but reasonable measure of severity for exchange rate and balanceof-payments crises. ${ }^{12}$

In table 3.4 we look at the largest annual change in real exchange rate

12. Note that we use changes in the real exchange rate because in some instances a large nominal depreciation simply matches high steady inflation and is not associated with a crisis. See Pivovarsky and Thaicharoen (2002) for a related analysis of exchange rate crises. 


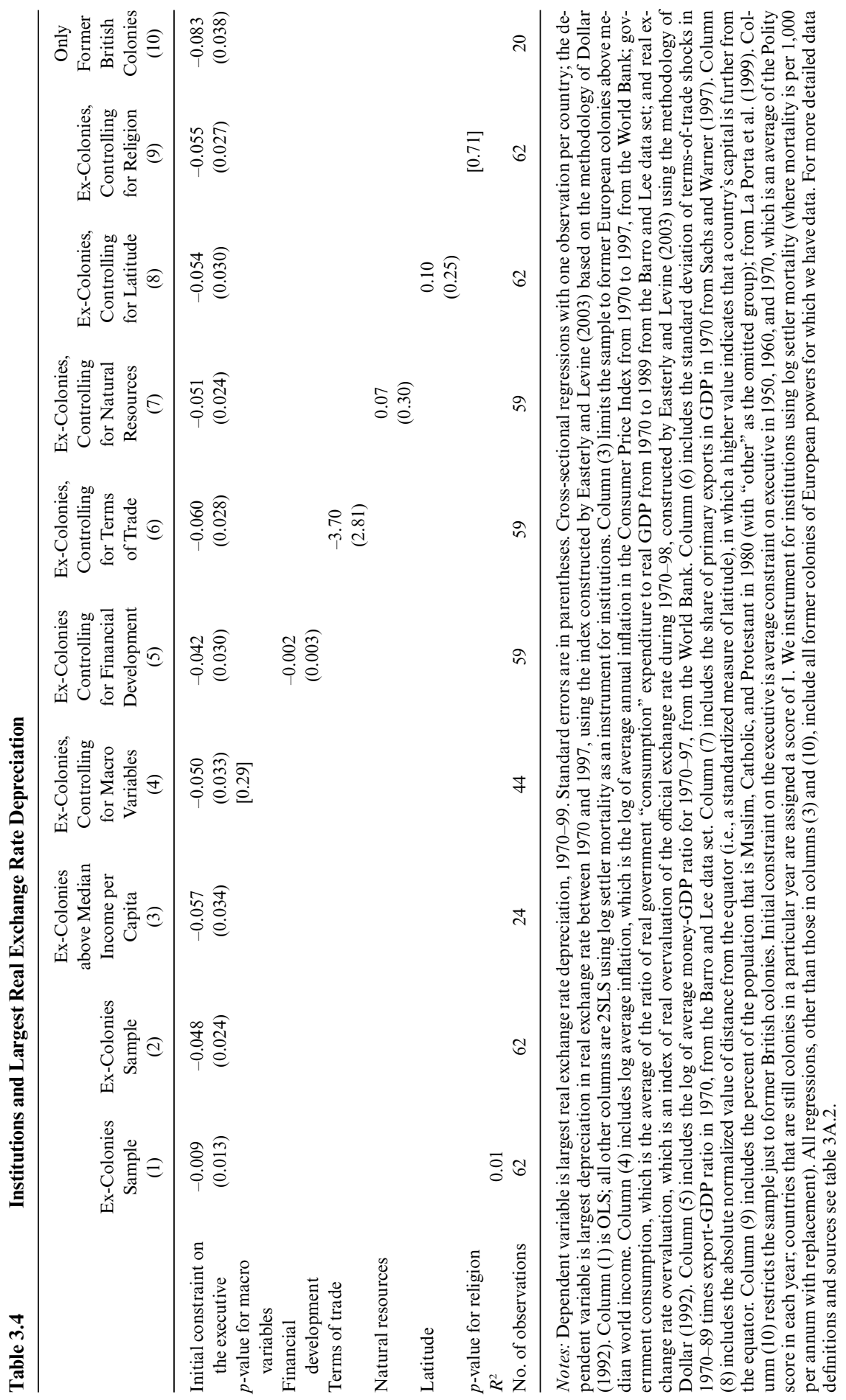




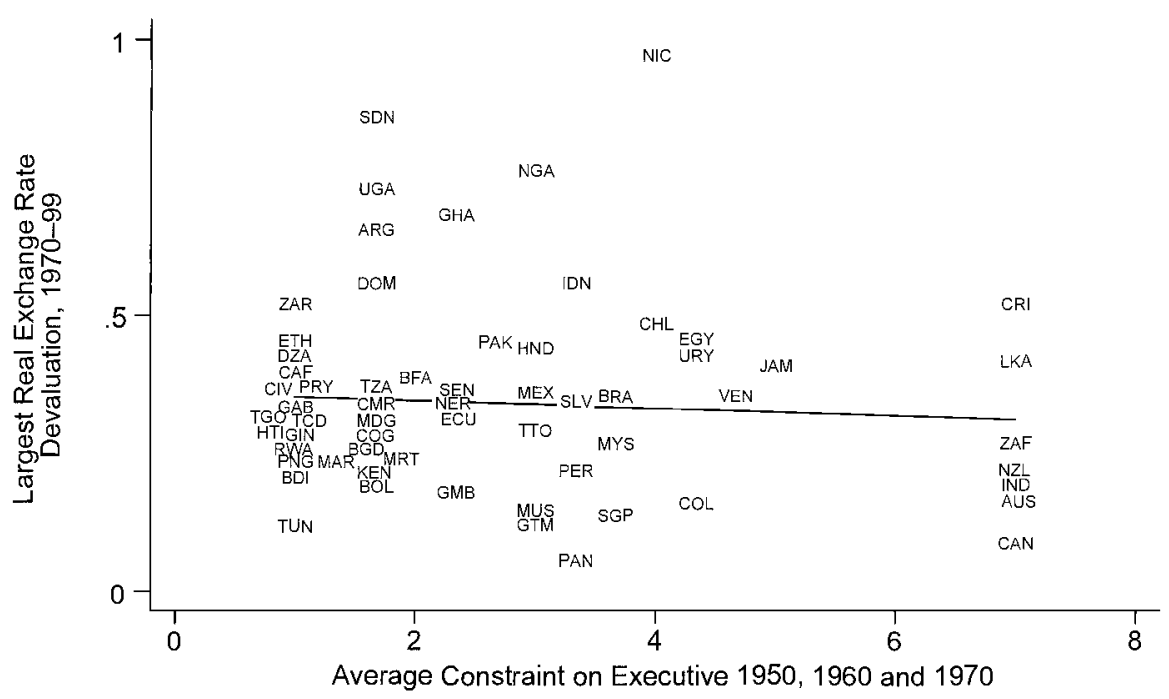

Fig. 3.8 Largest real depreciation against average constraint on executive

over the period 1970-99 using the index of the real exchange rate constructed by David Dollar (1992) and updated by Easterly and Levine (2003). The advantage of this measure is that it allows provides comparable data for almost all countries. ${ }^{13}$

Our dependent variable is expressed as a decimal, with a higher positive number indicating a larger real depreciation. We are comparing the "worst" (i.e., largest) real depreciation experience of countries. Figure 3.8 shows the OLS relationship. Countries with better institutions experienced a lower absolute value (i.e., less bad) "worst" real depreciation over this period. The OLS coefficient on institutions in column (1), -0.009 , indicates that countries with a 1 point better score in terms of institutions have a lower (in absolute value) "worst depreciation" by 0.9 percentage points.

When we instrument for institutions using log settler mortality, the coefficient on institutions increases in absolute size to -0.048 (with the standard error rising to 0.024). The coefficient estimate implies that over a thirty-year period Nigeria's worst exchange rate depreciation (i.e., arguably part of its worst balance-of-payments crisis) would be 20 percentage points higher than that of Canada - the actual difference was nearly 70 percentage points.

This large coefficient on institutions is confirmed in the alternative spec-

13. The real exchange rate is computed by Easterly and Levine (2003) as the average amount that domestic prices in U.S. dollars are higher than international prices in U.S. dollars. We omit the United States when we use maximum real devaluation as the dependent variable. However, the United States is included when we use the average real exchange rate overvaluation as a right-hand-side variable. 
ifications of table 3.4 (with the same structure of columns as tables 3.2 and 3.3). The coefficient on institutions is always at least -0.04 and is as large as -0.083 (for the British colonies only in column [10]) and is significant in all columns, except in columns (3), (4), and (5), where we respectively limit the sample to countries above median world income, control for the macro variables, and control for financial development. None of the control variables are significant in any specification we have investigated.

\subsubsection{Banking Crises}

Table 3.5 reports results using an indicator of "systemic" banking crises as the dependent variable. Our main data source is Barth, Caprio, and Levine (2002), who report data on banking systems, including an indicator of banking crises for ninety-two countries. However, they do not distinguish between large and small crises. For example, in their data the United States' savings and loans crisis is coded as a crisis, even though it involved a relatively small part of the financial system. To create a variable measuring "systemic crisis" we use information from Boyd, Kwak, and Smith (2002), who code whether there was a systemic or nonsystemic banking crisis for a smaller set of countries. ${ }^{14}$

We have data on banking crises only for 44 former colonies in total, with 25 countries suffering systemic banking crises over this time period. Out of this 44, we also do not have data on institutions or settler mortality for an additional 8 . Most of the missing countries are relatively poor countries in Africa. Therefore, these results on banking crises should be seen as quite tentative, mostly as suggesting a promising line for future research.

Column (1) shows an OLS coefficient on institutions of -0.1 , with a standard error of $0.04 .{ }^{15}$ When we instrument for institutions using settler mortality, the coefficient increases in absolute size to -0.15 and the standard error rises to 0.07 . This implies that the 4-point difference in institutional scores of Nigeria and the United States should translate into 0.6 difference in the probability of a systemic banking crisis, which is again a very large effect.

The coefficient on institutions is significant in all our alternative specifications, with the exception of column (5), where we control for financial development. The only control variables that are significant are the macro variables, which are jointly significant at the 10 percent level in column (4).

Looking just at the twenty countries that are above median world per capita income and for which we have data (column [3]) suggests a stronger

14. More specifically, we treat all the Barth, Caprio, and Levine (2002) crises as systemic unless Boyd, Kwak, and Smith (2002) indicate otherwise. As a result, Canada, India, and the United States are reclassified from 1 to 0.

15. We are estimating a linear probability model using OLS and IV. Such linear probability models are consistent with both OLS and IV, and, as argued by Angrist (2001), they are conceptually appealing, especially with IV. 


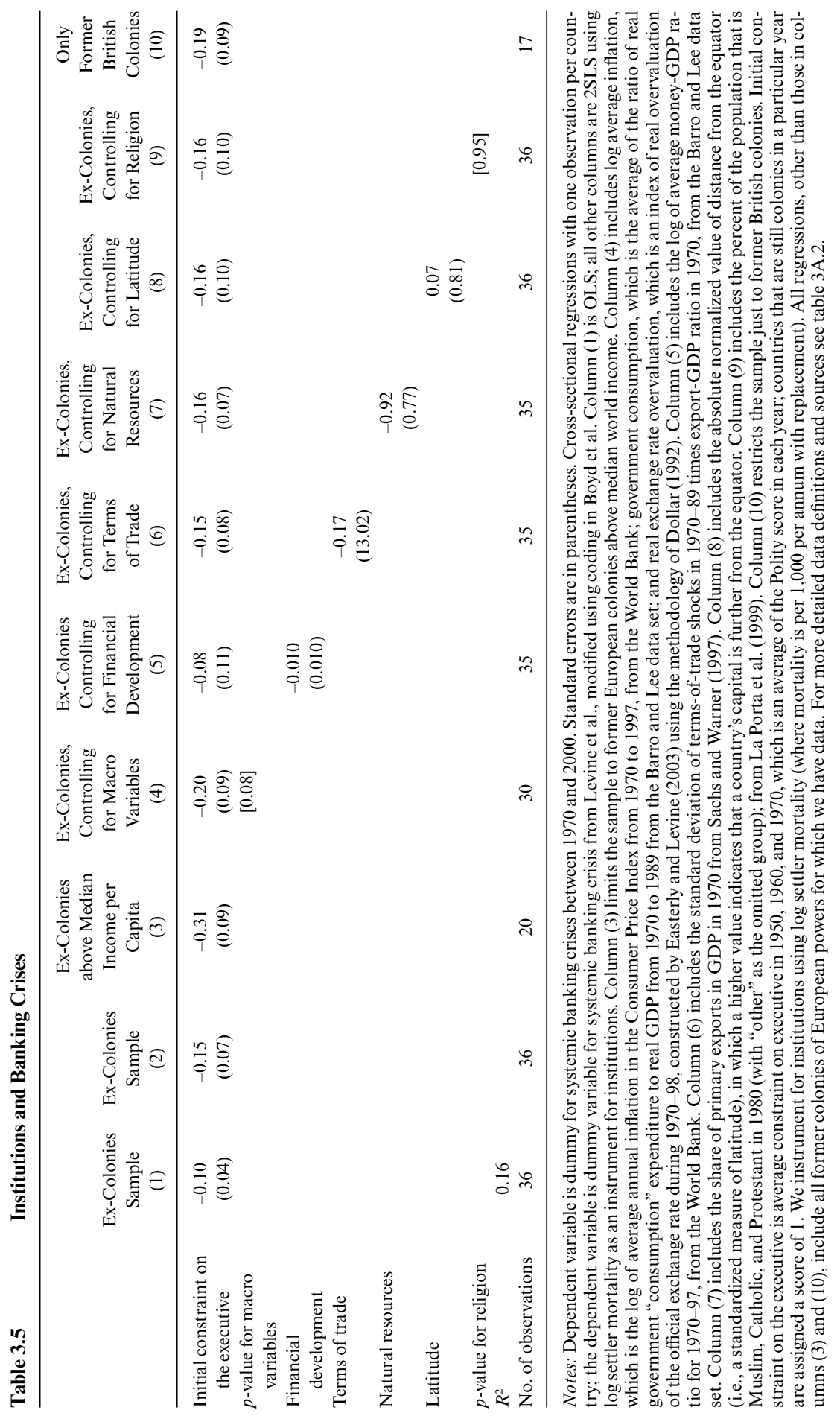


relationship than for the sample as a whole: a coefficient of -0.31 and a standard error of 0.09 . This suggests the possibility that institutions and income need to be above some threshold level before systemic banking crises occur. Given current data limitations, however, we regard this result with some caution. Nevertheless, the results in table 3.5 are quite consistent with what we find using more comprehensive data on output and exchange rates: Worse institutions lead to greater economic instability and crises.

\subsubsection{Political Crises}

Changes in power in institutionally weak societies may lead to economic instability, and institutional weaknesses encourage power struggles and increase the likelihood of major shifts in power. This subsection investigates whether major political crises are more likely when institutions are weak.

To measure political crises we use the data set of the State Failure Task Force (1998), which indicates periods of "state failures": that is, major political crises, such as civil wars, revolutions, and violent fighting between different factions. We supplement this data with information on revolutions from the Barro and Lee (1993) data set. We code a country as having had a political failure if it had either a state failure according to the State Failure Task Force (1998) or a revolution or both between 1960 and 1998. Of the 72 former colonies for which we have data, 56 had a political crisis defined in this way.

As with our analysis of banking crisis, we emphasize the need for further research on the issue of who exactly has had what kind of political crisis. We do not yet know how best to aggregate and compare these crises. Nevertheless, table 3.6 provides a preliminary look at the relationship between a dummy for "political failure" and initial constraint on the executive, instrumented by log settler mortality. Again, the robust if crude result is that countries with weak institutions at the beginning of the sample were more likely to suffer political failures of some kind over the past thirty to forty years.

Column (1) of table 3.6 shows an OLS estimate of -0.09 on institutions, with a standard error of 0.02 . As with the previous tables, the absolute value of the effect of institutions increases when we instrument using log settler mortality. In column (2), for example, the coefficient on institutions is -0.14 (standard error of 0.04), and in column (10), for just former British colonies, the coefficient is -0.16 (standard error of 0.07 ). This implies, for example, an approximately 0.56 difference in the probability of a political crisis between Nigeria and the United States.

The least significant result for institutions is again in column (5), when we control for financial development - the coefficient on institutions is significant at the 10 percent level. Again, financial development itself is not significant. None of the other control variables in table 3.6 are significant, apart from the macro policy variables (column [4]), which are jointly 


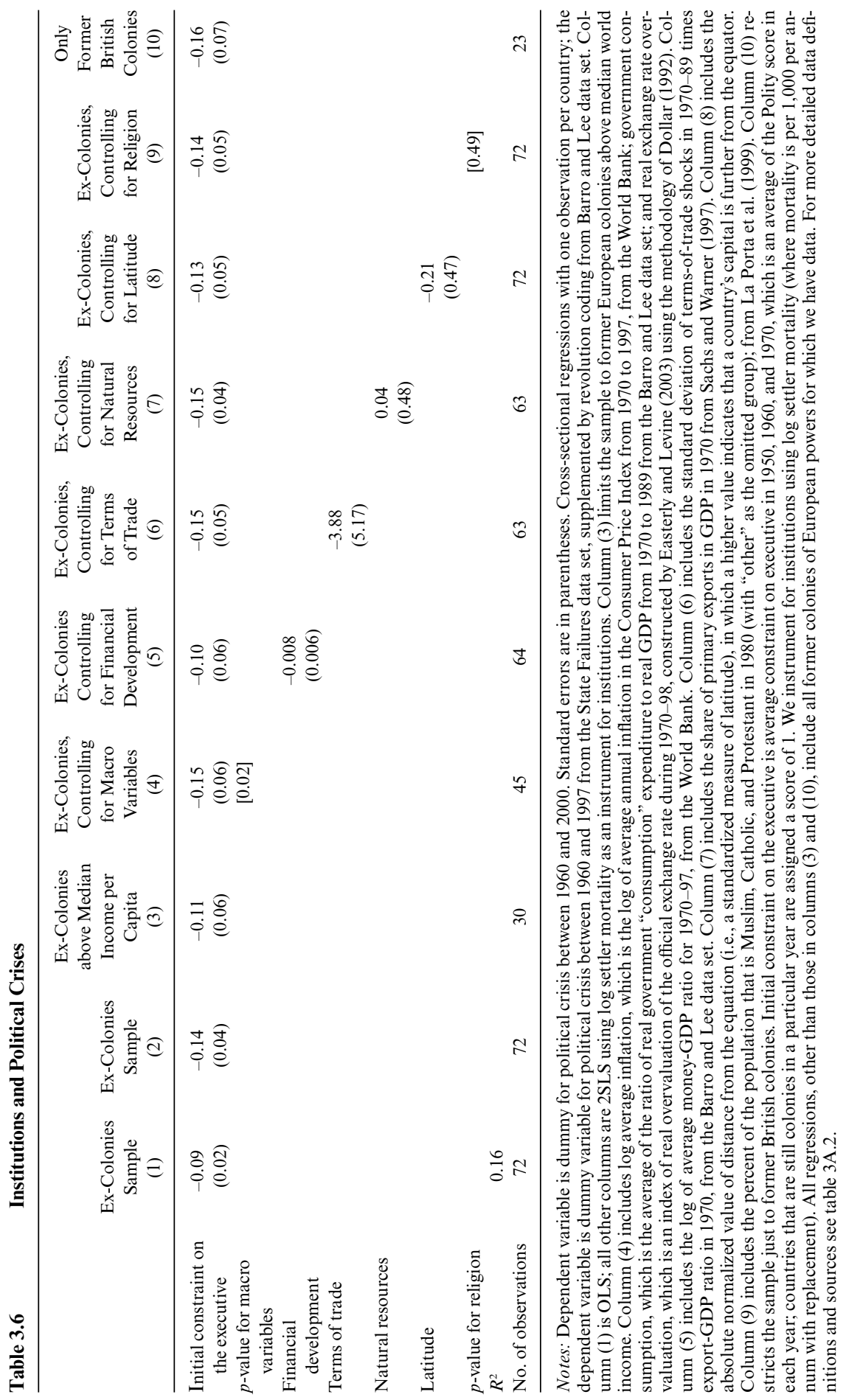


significant at the 5 percent level. Taken separately, government consumption and the overvaluation of the real exchange rate are significant: More government consumption is associated with greater probability of a political crisis, and a more appreciated real exchange rate is associated with a lower probability of a political crisis.

As with our analysis of banking crises, we regard these results for political crises as suggestive but very preliminary. We need more work that looks carefully at the determinants and effects of different kinds of crises. Nevertheless, table 3.6 suggests that political crises are in some way intimately tied to the process through which relatively weak institutions generate greater economic instability.

\subsection{Conclusion}

Taken together, the results presented in this paper suggest an important link between institutions and economic (and most likely political) instability. The historically determined component of institutions has a first-order effect on volatility, severity of economic crises, exchange rate crises, systemic banking crises, and political crises. This effect is robust to including the obvious control variables and to restricting the sample to just countries above median world income or just former British colonies. Our interpretation is that institutional differences across countries are a fundamental determinant of economic and political instability. However, a great deal more research is needed before we fully understand exactly how, when, and why institutions cause instability.

\section{Appendix}

Table 3A.1 Country Abbreviations

\begin{tabular}{ll|ll}
\hline Country's full name: & $\begin{array}{c}\text { Abbreviation } \\
\text { used in figures: }\end{array}$ & Country's full name: & $\begin{array}{c}\text { Abbreviation } \\
\text { used in figures: }\end{array}$ \\
\hline Argentina & ARG & Côte d'Ivoire & CIV \\
Australia & AUS & Cameroon & CMR \\
Burundi & BDI & Congo, Rep. & COG \\
Burkina Faso & BFA & Colombia & COL \\
Bangladesh & BGD & Costa Rica & CRI \\
Bolivia & BOL & Dominican Republic & DOM \\
Brazil & BRA & Algeria & DZA \\
Botswana & BWA & Ecuador & ECU \\
Central African Republic & CAF & Egypt, Arab Rep. & EGY \\
Canada & CAN & Ethiopia & ETH \\
Chile & CHL & Gabon & GAB \\
(continued $)$ & & &
\end{tabular}


Table 3A.1 (continued)

\begin{tabular}{|c|c|c|c|}
\hline Country's full name: & $\begin{array}{l}\text { Abbreviation } \\
\text { used in figures: }\end{array}$ & Country's full name: & $\begin{array}{l}\text { Abbreviation } \\
\text { used in figures: }\end{array}$ \\
\hline Ghana & GHA & Pakistan & PAK \\
\hline Guinea & GIN & Panama & PAN \\
\hline Gambia, The & GMB & Peru & PER \\
\hline Guatemala & GTM & Philippines, The & PHL \\
\hline Honduras & HND & Papua New Guinea & PNG \\
\hline Haiti & HTI & Paraguay & PRY \\
\hline Indonesia & IDN & Rwanda & RWA \\
\hline India & IND & Sudan & SDN \\
\hline Jamaica & JAM & Senegal & SEN \\
\hline Kenya & $\mathrm{KEN}$ & Singapore & SGP \\
\hline Sri Lanka & LKA & El Salvador & SLV \\
\hline Lesotho & LSO & Chad & TCD \\
\hline Morocco & MAR & Togo & TGO \\
\hline Madagascar & MDG & Trinidad and Tobago & TTO \\
\hline Mexico & MEX & Tunisia & TUN \\
\hline Mozambique & MOZ & Tanzania & TZA \\
\hline Mauritania & MRT & Uganda & UGA \\
\hline Mauritius & MUS & Uruguay & URY \\
\hline Malawi & MWI & United States & USA \\
\hline Malaysia & MYS & Venezuela, RB & VEN \\
\hline Niger & NER & South Africa & $\mathrm{ZAF}$ \\
\hline Nigeria & NGA & Congo, Dem. Rep. & ZAR \\
\hline Nicaragua & NIC & Zambia & $\mathrm{ZMB}$ \\
\hline Nepal & NPL & Zimbabwe & ZWE \\
\hline New Zealand & NZL & & \\
\hline
\end{tabular}




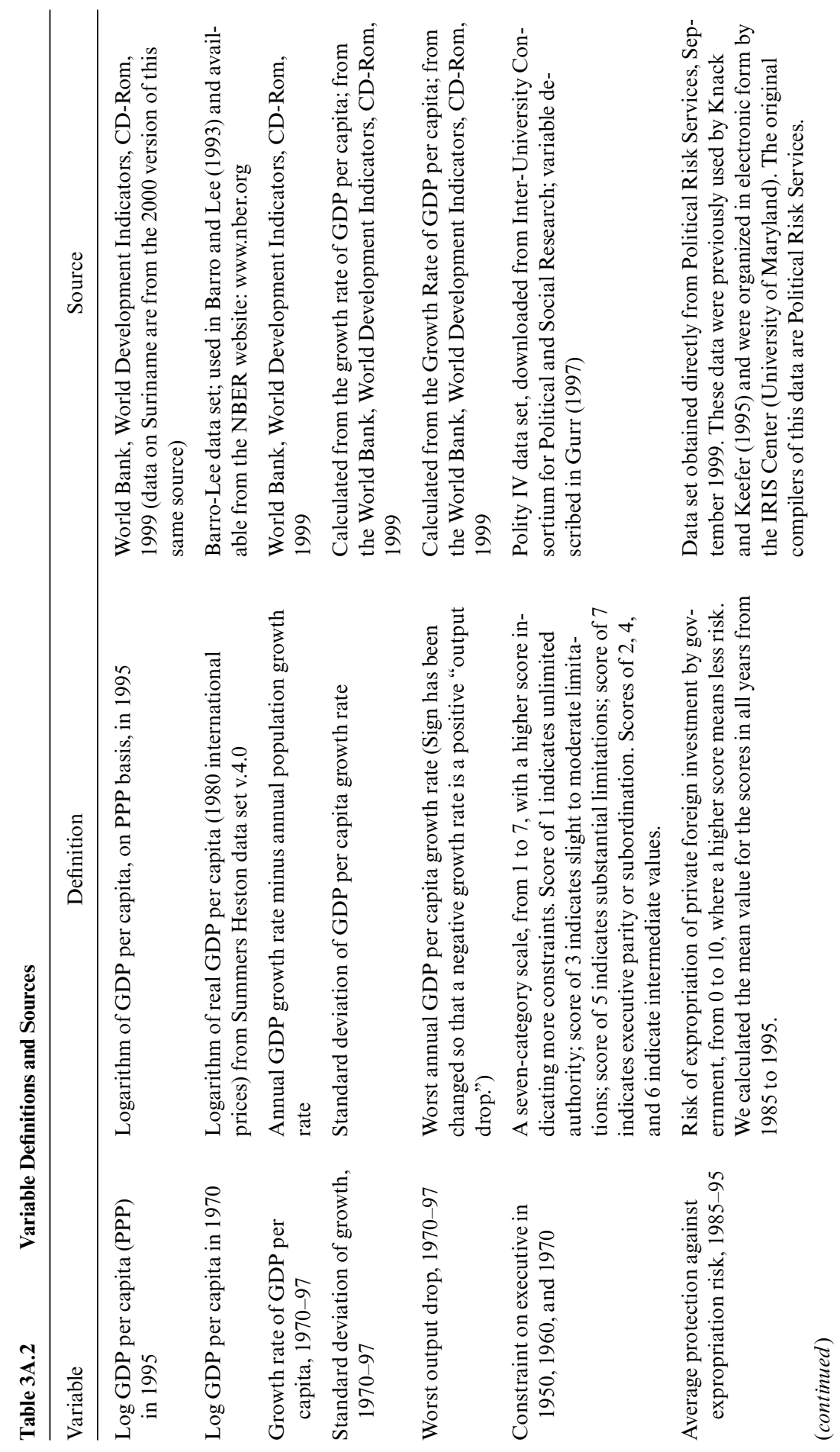




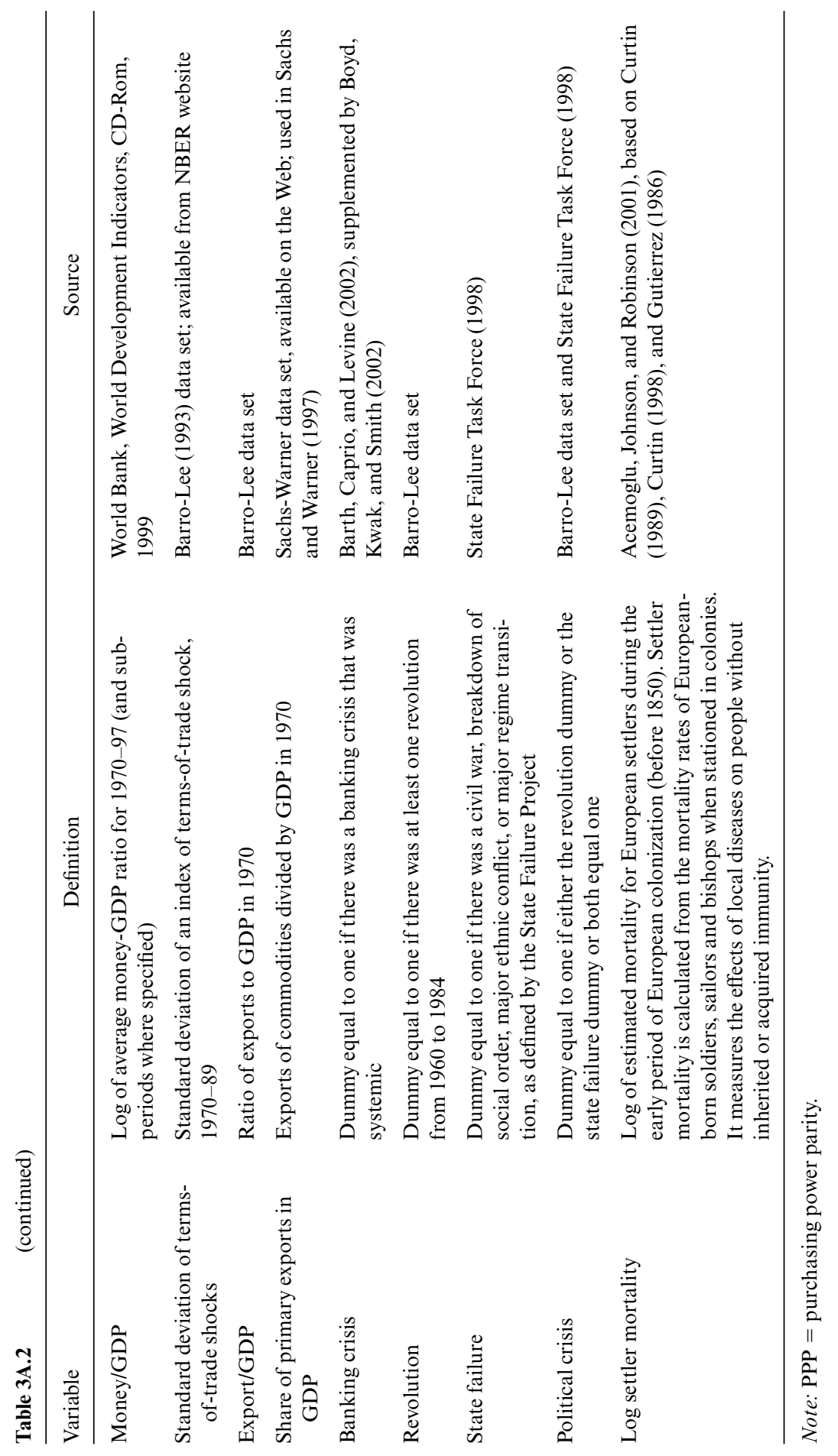




\begin{tabular}{llcr}
\hline & \multicolumn{3}{c}{ Ex-Colonies Sample } \\
\cline { 2 - 4 } & $\begin{array}{l}\text { Mean } \\
\text { Value }\end{array}$ & $\begin{array}{c}\text { 25th } \\
\text { Percentile }\end{array}$ & $\begin{array}{c}\text { 75th } \\
\text { Percentile }\end{array}$ \\
\hline $\begin{array}{l}\text { Annual growth GDP per capita, 1970-97 } \\
\begin{array}{l}\text { Standard deviation of growth } \\
\quad \text { (GDP per capita), 1970-97 }\end{array}\end{array}$ & 1.07 & 0.09 & 1.95 \\
$\begin{array}{l}\text { Worst drop output (GDP per capita), } \\
\quad \text { 1970-97 }\end{array}$ & 4.68 & 3.44 & 5.69 \\
$\begin{array}{l}\text { Average constraint on the executive } \\
\text { in 1950, 1960, and 1970 }\end{array}$ & 9.03 & 6.05 & 14.23 \\
\hline
\end{tabular}

Note: For detailed sources and definitions see table 3A.2.

\section{References}

Acemoglu, Daron, Simon Johnson, and James A. Robinson. 2001. Colonial origins of comparative development: An empirical investigation. American Economic Review 91:1369-401.

- 2002. Reversal of fortune: Geography and institutions in the making of the modern world income distribution. Quarterly Journal of Economics 117:1231-94.

Acemoglu, Daron, Simon Johnson, James A. Robinson, and Yunyong Thaicharoen. 2003. Institutional causes, macroeconomic symptoms: Volatility, crises, and growth. Journal of Monetary Economics 50 (1): 49-123.

Acemoglu, Daron, and Fabrizio Zilibotti. 1997. Was Prometheus unbound by chance? Risk, diversification, and growth. Journal of Political Economy 105: 1167-200.

Angrist, Joshua D. 2001. Estimations of limited dependent variable models with dummy endogenous regressors: Simple strategies for empirical practice. Journal of Business and Economic Statistics 19 (1): 2-16.

Barro, Robert J. 1991. Economic growth in a cross section of countries. Quarterly Journal of Economics 106:407-33.

Barro, Robert J., and Jong-Wha Lee. 1993. International comparisons of educational attainment. Journal of Monetary Economics 32:363-94.

Barth, James R., Gerard Caprio, Jr., and Ross Levine. 2002. Banking systems around the globe: Do regulation and ownership affect performance and stability? World Bank, Auburn University, and University of Minnesota. Unpublished manuscript.

Boyd, John H., Sungkyu Kwak, and Bruce Smith. 2002. The real output losses associated with modern banking crises, or, "the good, the bad, and the ugly." University of Minnesota and University of Texas at Austin. Manuscript, February.

Curtin, Philip D. 1989. Death by migration: Europe's encounter with the tropical world in the 19th century. New York: Cambridge University Press.

1998. Disease and empire: The health of European troops in the conquest of Africa. New York: Cambridge University Press.

Dollar, David. 1992. Outward oriented developing economies really do grow more rapidly. Economic Development and Cultural Change 40:523-44.

Easterly, William, Roumeen Islam, and Joseph Stiglitz. 2000. Shaken and stirred: 
Explaining growth volatility. In Annual World Bank conference on development economics, 191-211. Washington, D.C.: The World Bank. April.

Easterly, William, and Ross Levine. 2003. Tropics, germs, and crops: How endowments influence economic development. Journal of Monetary Economics 50 (1): 3-39.

Gurr, Ted Robert. 1997. Polity II: Political structures and regime change, 1800-1986. University of Colorado, Department of Political Science. Unpublished manuscript.

Gutierrez, Hector. 1986. La mortalité des eveques Latino-Americains aux XVIIe et XVIII siècles (Mortality of Latin American bishops in the seventeenth and eighteenth centuries). Annales de Demographie Historique, 29-39.

Hall, Robert E., and Charles I. Jones. 1999. Why do some countries produce so much more output per worker than others? Quarterly Journal of Economics 114:83-116.

Heston, Alan, Robert Summers, and Bettina Aten. 2002. Penn World Table version 6.1. Philadelphia: Center for International Comparisons at the University of Pennsylvania, October.

Jones, Eric L. 1981. The European miracle: Environments, economies, and geopolitics in the history of Europe and Asia. New York: Cambridge University Press.

Knack, Stephen, and Philip Keefer. 1995. Institutions and economic performance: Cross-country tests using alternative measures. Economics and Politics 7:207-27.

La Porta, Rafael, Florencio Lopez-de-Silanes, Andrei Shleifer, and Robert W. Vishny. 1998. Law and finance. Journal of Political Economy 106:1113-55.

. 1999. The quality of government. Journal of Law, Economics, and Organization 15 (1): 222-79.

Mauro, Paolo. 1995. Corruption and growth. Quarterly Journal of Economics 110 (3): 681-782.

North, Douglass C. 1981. Structure and change in economic history. New York: W. W. Norton.

North, Douglass C., and Robert P. Thomas. 1973. The rise of the Western world: A new economic history. Cambridge, U.K.: Cambridge University Press.

Olson, Mancur. 1982. The rise and decline of nations: Economic growth, stagflation, and economic rigidities. New Haven, Conn.: Yale University Press.

Pivovarsky, Alexander, and Yunyong Thaicharoen. 2002. Institutions and the severity of currency crises. MIT, Department of Economics, and Harvard University, Kennedy School of Government. Unpublished manuscript.

Sachs, Jeffrey D., and Andrew Warner. 1997. Fundamental sources of long-run growth. American Economic Review: Papers and Proceedings 87 (2): 184-88.

State Failure Task Force. 1998. State Failure Task Force report: Phase II findings. Prepared by Daniel C. Esty, Jack A. Goldstone, Ted Robert Gurr, Barbara Huff, Marc Levy, Geoffrey D. Dabelko, Pamelo T. Surko, and Alan N. Unger. McLean, Va.: Science Applications International Corporation, 31 July.

\section{Comment Steve Dowrick}

This paper is part of an ongoing and important research program into the impact of current institutions on economic development. In an earlier paper, Acemoglu, Johnson, and Robinson (2001) proposed a novel solution

Steve Dowrick is professor of economics and ARC Senior Research Fellow in the School of Economics, Australian National University. 
to the problem of identifying the exogenous component of institutional quality in their analysis of the determinants of the current levels of real GDP per capita in countries that had been subject to European colonization. Their instrumental variable was the mortality rate among the clergy and military at the beginning of the colonization period. Their argument is that these mortality rates were well recorded and publicized, influencing the subsequent pattern of European settlement and hence not only the nature of colonial institutions of property rights and democracy but also the nature of current institutions. Furthermore, they presented evidence that the impact of disease on the early colonizers was distinct from its impact on the indigenous population, both then and now.

Here the same approach is taken to identifying the impact of current institutions on various measures of economic volatility, including the variability of output growth, exchange rate depreciation, banking crises, and political crises.

The authors' solution to the identification problem is ingenious. It is backed up convincingly both by a well-researched historical narrative (presented in more detail in their earlier paper) and by careful statistical testing of the requirement that their instrumental variable should be orthogonal to a range of other variables that might influence their dependent variables, such as inflation and terms-of-trade shocks and latitude. Of course, one could continue to search for other variables that are correlated with settler mortality and also influence current volatility, but to my mind the authors have canvassed the most likely candidates, and their results do appear to be robust.

In fact, my only concern with the paper is that the authors have probably overstated the economic significance of their results. Although they have identified the impact of the exogenous component of institutional quality on volatility, that impact may be relatively small compared with other influences on volatility. For example, the paper compares the predicted impact of institutional quality on the difference in output growth volatility between the United States and Nigeria, finding that the difference in quality scores explains two-thirds of the difference in volatility. Examination of figure 3.2, which illustrates the scatter plot of output volatility against the instrumental variable, suggests that the authors have chosen to compare a pair of countries most favorable to their hypothesis. Nigeria and the United States are not only close to the extremes of the settler mortality variable, but also close to the linear regression line illustrated in the figure. Since settler mortality is the only instrumental variable, the predicted effect of institutional quality in the two-stage least squares (2SLS) estimation is likely to be close to the illustrated ordinary least squares (OLS) regression on the instrument. Hence, the choice of a pair of countries lying further away from the regression line-for example, comparing Indonesia with Gabon, or comparing Mali with Fiji-would probably lead to the conclusion that institutional quality differences explain relatively little of the difference in volatility. 
Rather than examining the predictions of their model for an arbitrary pair of countries, the authors should compare all the predicted values of their 2SLS regression with the actual values, perhaps reporting the correlation coefficient. I suspect that they will find that their instrumented measure of institutional quality does not explain a large part of the overall variance in measures of volatility. If so, that is important to note. But it does not detract from the value of the paper in identifying an exogenous component of institutional quality and demonstrating that it has a systematic and robust impact on economic volatility.

\section{Reference}

Acemoglu, Daron, Simon Johnson, and James A. Robinson. 2001. Colonial origins of comparative development: An empirical investigation. American Economic Review 91 (5): 1369-401.

\section{Comment Dipinder S. Randhawa}

Simon Johnson and his coauthors (hereafter AJR) offer a remarkably lucid, creative, and cogent analysis of the origins of institutions and their links to current economic performance. This paper contends that societies that for historical reasons have weak institutions have suffered substantially more output volatility and experienced more severe output contraction, exchange rate depreciation, and banking and political crisis over the past thirty years.

It is an extension of the authors' earlier work examining differential rates of growth among former European colonies. The line of reasoning, drawing upon data on mortality rates among bishops, sailors, and soldiers from the seventeenth to the nineteenth centuries, contends that the mortality rates among the European settlers influenced the prospects for settlements. Evolving settlements in turn led to the creation of institutions. The legacy of these institutions was sustained into the postcolonial period with profound implications for economic growth (Acemoglu, Johnson, and Robinson 2001). This paper extends the analysis to look at the origins of instability and crisis in developing economies.

The focus is on countries colonized by the European powers. The authors document that different colonization strategies and different institutions set up by Europeans had radically different implications for economic development. Places prospered when Europeans "set up institu-

Dipinder S. Randhawa is a teaching fellow at the National University of Singapore Business School. 
tions that protected private property rights, enforced the rule of law, and placed tight constraints on politicians and powerful elites. In contrast, areas where Europeans established new extractive institutions, or took over existing ones, stagnated or grew only slowly."

The current project constitutes a valuable addition to the literature linking institutional structures with long-term development. The logic is compelling. The stated objective is to demonstrate "the effect of historical institutions on economic development by exploiting variation in the feasibility of large-scale settlements by Europeans." Accordingly, Europeans built settlements in areas where the incidence of mortality and morbidity was low. Areas with high incidence of disease and mortality were not deemed attractive for settlement. The differential settlement patterns resulting from differences in mortality rates resulted in distinct patterns of economic activity. In areas where settlers suffered high mortality rates, the form of economic exchange was extractive. In these areas, the colonizers were much more likely to exploit the native population for the benefit of a few rich Europeans, and these institutions have proved incompatible with sustained rapid growth.

Based on this approach, AJR use mortality rates faced by European settlers as an instrumental variable for institutional development and current institutions. There is a strong and robust relationship between per capital income growth rates (as a measure of long-term development) and mortality rates. The interpretation is that this relationship reflects the effect of historically determined institutions (more specifically, institutions shaped by differential European settlement patterns) on instability. They further contend that not only did societies that inherited extractive institutions from their colonial past fail to take advantage of development opportunities over the long run, but their recent medium-run experience has been characterized by frequent crises and substantial instability.

\section{Causality (Embedded and Explicit)}

A first reading of the paper may be misleading. Although proposed as such in the text, the data at hand and a perusal of the demographics of settlements do not suggest a monotonic relationship between mortality rates and settlements - an embedded assumption, albeit not crucial to the central relationship between the development of institutions and crisis. It seems unlikely we can obtain a monotonic relationship among experiences as diverse as the Spanish expansion in Latin America, which resulted in large European settlements in the midst of high mortality rates, or the Dutch in Indonesia, where high mortality rates led to small settlements yet the small cohort of settlers remained engaged primarily in lucrative intraregional trade.

A clearer line of causality emerges from the postcolonial institutional setup and its impact on economic development and vulnerability of the 
economy to crisis. That there is continuity in the development and effectiveness of institutions in the pre- and postcolonial periods is widely acknowledged, but the embedded contention that these institutional characteristics are immutable over time is yet to be established. The import of this assertion, seemingly an illustration of predestination, is that postcolonial initiatives toward institutional development matter little for economic performance. It implicitly abstracts from postcolonial policy regimes and all the changes therein - where, at the very least, a number of economies transitioned from an import substitution strategy of industrialization to export orientation, often with commensurate changes in institutional structures. The measures and proxies of institutions deployed all draw upon institutional constructs of the past thirty years (contemporary institutions).

A switching regime model to ascertain whether there is a change in the colonial regime and postindependence policy regime would provide validation for implicit causality and offer a direct link between current performance and regimes established during the colonial period. At issue also are questions about the robustness of instrumental variables, including mortality rates.

The innovative use of mortality rates as an instrumental variable for settlements and institutional development during the colonial expansion is fascinating; however, its linkages with current institutions, on both the theoretical (or intuitive) and the empirical plane, are less clear. Incorporation of a control variable reflecting postindependence policy regimes may strengthen the line of causation. This assumes importance given the variability in regimes across and within (chronologically) former colonies. It leaves open an arena for subsequent research to inquire into the linkages between institutions, macroeconomic policy, and economic performance.

\section{Proxies for Instability}

The AJR paper uses five proxies for instability: output volatility, the most severe drop in output, largest exchange rate depreciation, and dummy variables for banking crises and political crises. The results are tabulated in table 3C.1. By and large, the findings lend support to the choice of the instrumental variable; nevertheless, considerable ambiguity prevails. The authors propose the framework as a blueprint to encourage other researchers to delve into the area.

Data problems on a project of this scope are substantial. A rich retinue of macroeconomic variables testifies to the robustness of the instrumental variable, especially vis-à-vis output volatility and the worst loss in output. Variation in output is an appealing measure of volatility. The choice of worst drop in output over a period in excess of twenty-five years raises a few questions. The prevailing exchange rate regime, the extent of openness of the economy, and the timing of external help or of implementation of an International Monetary Fund program have significant ramifications for 


\begin{tabular}{lll}
\hline Proxy for Instability & \multicolumn{1}{c}{ Variable } & \multicolumn{1}{c}{$\begin{array}{c}\text { Result for Instrumental Variable } \\
\text { (mortality levels) }\end{array}$} \\
\hline Output volatility & $\begin{array}{l}\text { Standard deviation of PCY GDP } \\
\text { growth rate }\end{array}$ & Significant \\
Worst drop in output & $\begin{array}{l}\text { Worst annual PCY GDP growth rate } \\
\text { Standard deviation of terms-of-trade }\end{array}$ & $\begin{array}{l}\text { Significant } \\
\text { Significant, except when controlled } \\
\text { for financial development and macro } \\
\text { policy variables }\end{array}$ \\
& Binary (dummy) variable & $\begin{array}{l}\text { Significant, except when controlled } \\
\text { for financial development and macro } \\
\text { policy variables }\end{array}$ \\
Banking crisis & Binary (dummy) variable & $\begin{array}{l}\text { Significant, except when controlled } \\
\text { for financial development and some } \\
\text { macro policy variables }\end{array}$ \\
& &
\end{tabular}

Note: $\mathrm{PCY}=$ per capita income.

output loss during a crisis, as would the nature of the crisis (i.e., systemic or otherwise).

The proxy for exchange rate crisis - the magnitude of exchange rate depreciation - is likely to be impacted by all the factors previously mentioned, including openness of the economy and the nature of the exchange rate crisis.

Considering banking and political crises as binary variables may have contributed to the indecisive results - in the case of the former, a widely used measure conveying the intensity of the crisis is the cost (in terms of GDP) of rehabilitating the banking sector.

The intuition behind using measures such as "the largest drop in output" or the "percentage depreciation" is not clear. There is a large body of literature that addresses the role of policy regimes, the extent of openness of the economy, and the level of indebtedness as being the prime determinants of the intensity of the crisis.

\section{Financial Development}

The debate on what constitutes an appropriate measure of financial development and, if we do agree on the issue, what indeed a measure of financial development does reflect, is an open issue. Therein may lie the answer to the ambiguous results obtained for the two measures of crisis.

The proxy M2/GDP, a widely used measure of financial development, reflects the extent of monetization of the economy. In a broader sense, financial development is now deemed to reflect not only the efficacy of intermediation but also the screening and monitoring functions performed by markets and institutions. A single-dimensional variable may not be ad- 
equately equipped to reflect these attributes. Studies have documented strong relationships between financial liberalization and financial development - the primary motivation behind the recommendation of deregulation of the financial sector. Experiences dating back to Chile and the Southern Cone of Latin America in the late seventies and early eighties testify to the folly of blanket deregulation, in contrast to the more interventionist policy regimes among the two generations of Asian tigers, which was an essential construct underlying the Asian Miracle. Of course, some deem the same set of policies to have undone the "miracle" in 1997. Perhaps the route to take on this issue is the one sought by a number of researchers in the literature on financial crisis: that is, to seek that configuration of institutional frailties and macroeconomic vulnerabilities that give rise to financial fragility and crisis.

The debate on the speed and extent of financial liberalization remains unresolved. Positive real interest rates almost unequivocally lead to financial deepening (increasing M2/GDP). Strengthening of institutions for financial development requires a range of commensurate initiatives that researchers are yet to pin down. As the authors point out, the precise mechanisms (linking institutions with growth and instability) are not clear, and a great deal more research is needed on the theoretical and empirical relationship between institutional weaknesses and instability.

Along with its precursor (Acemoglu, Johnson, and Robinson 2001), this paper performs a stellar role in laying out a blueprint for inquiring into the origins of institutions and delineating their impact on growth and stability. One would expect a new strand of the literature tackling the range of issues addressed in this paper. To that end, the authors not only have made a valuable contribution, but will indeed have provided an impetus to research in the field.

\section{Reference}

Acemoglu, Daron, Simon Johnson, and James A. Robinson. 2001. The colonial origins of comparative development: An empirical investigation. American Economic Review 91:1369-1401. 